\title{
The origin of the palladium particle size effects in the direct synthesis
}

\section{of $\mathrm{H}_{2} \mathrm{O}_{2}$ : Is smaller better?}

\author{
Pengfei Tian ${ }^{\mathrm{a}, 1}$, Like Ouyang ${ }^{\mathrm{a}, 1}$, Xingyan $\mathrm{Xu}{ }^{\mathrm{a}}$, Can Ao ${ }^{\mathrm{a}}$, Xinchao $\mathrm{Xu}{ }^{\mathrm{a}}, \mathrm{Rui} \mathrm{Si}^{\mathrm{b}}$, \\ Xiangjian Shen ${ }^{c}$, Ming Lin ${ }^{\mathrm{d}}$, Jing Xu ${ }^{\mathrm{a}, *}$, and Yi-Fan Han ${ }^{\mathrm{a}, \mathrm{c}, *}$
}

\section{Affiliations:}

${ }^{a}$ State Key Laboratory of Chemical Engineering, East China University of Science and Technology, Shanghai 200237, China.

${ }^{\mathrm{b}}$ Shanghai Synchrotron Radiation Facility, Shanghai Institute of Applied Physics, Chinese Academy of Sciences, Shanghai 201204, China.

${ }^{c}$ Research Center of Heterogeneous Catalysis and Engineering Sciences, School of Chemical Engineering and Energy, Zhengzhou University, Zhengzhou 450001, China.

${ }^{\mathrm{d}}$ Institute of Materials Research and Engineering (IMRE), A* STAR, 138634, 3 Singapore.

$5 *$ Correspondence to:

6 E-mail: yifanhan@ecust.edu.cn; xujing@ecust.edu.cn.

7 Tel: +86-21-64251928. Fax: +86-21-64251928 


\section{ABSTRACT:}

A series of size-controlled Pd/hydroxyapatite (HAp) catalysts ranging from single sites (Pd clusters) to nanoparticles $\left(\mathrm{d}_{\mathrm{Pd}}: \sim 30 \mathrm{~nm}\right.$ ) was prepared and examined for the $\mathrm{H}_{2} \mathrm{O}_{2}$ synthesis directly from $\mathrm{H}_{2}$ and $\mathrm{O}_{2}$. A Pd/HAp ( $\mathrm{d}_{\mathrm{Pd}}$ : $\left.\sim 1.4 \mathrm{~nm}\right)$ showed a high selectivity of $94 \%$ toward $\mathrm{H}_{2} \mathrm{O}_{2}$ under mild conditions $(283 \mathrm{~K}$ and atmospheric pressure). The crystal phase, morphology, surface electronic states and coordination number of Pd particles from atomic level to nano scale were characterized in detail using multi-techniques such as X-rays diffraction, scanning transmission electron microscopy and the extended X-rays absorption fine structure. Density functional theory calculations indicated that Pd clusters in subnano size have the most effective active sites for the selective activation of oxygen hydrogenation, thus resulting in the high catalytic efficiency for $\mathrm{H}_{2} \mathrm{O}_{2}$ synthesis. This work elucidates those smaller Pd particles only in a proper size-range show the best catalytic performance for $\mathrm{H}_{2} \mathrm{O}_{2}$ synthesis.

Keywords: size effects, subnano clusters, $\mathrm{Pd} / \mathrm{HAp}$ catalysts, $\mathrm{H}_{2} \mathrm{O}_{2}$ synthesis, structure-performance relationship 


\section{Introduction}

The origin of size effects has long been a spotlight in the field of heterogeneous catalysis [1-6]. Nowadays, many efforts have been contributed to the characterization of active sites over catalysts, in which the size of metal particles is usually larger than ca. $2.5 \mathrm{~nm}$, a so-called magic size from non-metallic to metallic property for metal particles $[7,8]$. More recent studies have proven that active sites of practical metal catalysts may contain a certain amount of single sites [9-11] or clusters [12], or to say, the metal particles in the subnano size, which probably act as active components [13]. Nevertheless, it is still a great challenge to understand the origin of particle size effects, especially, to establish the structure-performance relationship of those catalysts with subnano size. On the other hand, is the smaller size better for catalysis? This question has intrigued a lot of debate on both academe and industry for the last years, and it is of importance to the rational design and controllable synthesis of industrial catalysts [14-17].

In this work, our strategy is to prepare a series of size-controlled Pd catalysts, which ranges from single sites (atomic level) to nanoparticles (ca. $30 \mathrm{~nm}$ ). We examine their catalytic performance for the direct $\mathrm{H}_{2} \mathrm{O}_{2}$ synthesis, which is regarded as a dreamful route to produce this greener oxidant, instead of an alternative of the current Riedl-Pfleiderer process involving sequential hydrogenation and oxidation of an anthraquinone [18]. It will greatly optimize the oxidation processes if coupling with oxidation process using $\mathrm{H}_{2} \mathrm{O}_{2}$ as an oxidant [19-24]. Actually, high selectivity toward $\mathrm{H}_{2} \mathrm{O}_{2}$ is difficult to achieve, since most of catalysts that are effective for the 
formation of $\mathrm{H}_{2} \mathrm{O}_{2}$ increase the production of undesirable water as well [25-30]. It is worthy to emphasize that the selective hydrogenation of $\mathrm{O}_{2}$ is also of great importance to the development of fuel cells [31, 32].

Our preliminary studies have revealed that the electronic structure of the surface Pd atoms in a $\mathrm{Pd} / \mathrm{TiO}_{2}$ catalyst could be tuned by forming $\mathrm{Pd}-\mathrm{PdO}$ ensembles, and the maximum $\mathrm{H}_{2} \mathrm{O}_{2}$ selectivity of ca. $60 \%$ was achieved without promoters [33]. With the optimization of reaction conditions, such as pressure, solvent, and the addition of promoters and acids, the selectivity could be improved to about $80 \%$ [26]. Remarkable increase in $\mathrm{H}_{2} \mathrm{O}_{2}$ selectivity could be obtained over Pd-M (M: Au, Pt etc.) bimetallic catalysts [34-38]. More recently, the Hutchings' group has reported selectivities of over 95\% using Pd-Au and Pd-Sn alloy catalysts [39, 40]. Nevertheless, the achievement of such a high selectivity for monometallic Pd catalysts is still a challenge.

Herein, we prepared a series of $\mathrm{Pd}(0.5 \sim 5.0 \mathrm{wt} \%) /$ Hydroxyapatite (HAp) catalysts using the ion-exchange method (I.E.) to prepare the single sites catalyst and the incipient wetness impregnation method to control the size of Pd particles. The catalytic performance was examined under mild conditions using a semi-batch micro tri-phase reactor [33]. The microstructure and dimensional constraints of $\mathrm{Pd}$ particles and the proximity between metal atoms and clusters are characterized using multi-techniques; meanwhile, the surface structure of Pd particles, especially, the formation of $\mathrm{Pd} / \mathrm{PdO}_{\mathrm{x}}$ interface and its relevance to the $\mathrm{Pd}$ particle size are identified. Finally, the models of active sites are proposed on the basis of density functional 
theory (DFT) calculations. We believe the combination of experimental evidences with the DFT calculations can shed a light on the origin of particle size effects on the catalytic performance.

\section{Experimental}

\subsection{Catalyst preparation}

HAp, as the support, was prepared by chemical precipitation of $\mathrm{Ca}\left(\mathrm{NO}_{3}\right)_{2}$ and $\left(\mathrm{NH}_{4}\right)_{2} \mathrm{HPO}_{4}$, more details of the preparation was given in Supplementary Information (SI). The crystal structure of HAp is shown in Fig. S1 [41]. Catalysts were prepared by incipient wetness impregnation using an aqueous solution of $\mathrm{PdCl}_{4}{ }^{2-}$ as described in a previous study [33]. The single-site Pd catalyst was prepared by the ion-exchange method (denoted as Pd(I.E.), in which the HAp (995 mg) was added into $300 \mathrm{~mL}$ deionized water and mixed with $1 \mathrm{~mL} \mathrm{Pd}^{2+}$ solution $(0.05 \mathrm{~mol} / \mathrm{L})$ for $48 \mathrm{~h}$ at $343 \mathrm{~K}$, then filtered and dried at $383 \mathrm{~K}$ for another $24 \mathrm{~h}$, the Pd loading is $0.5 \mathrm{wt} \%$.

To investigate the effect of calcination temperature, precursors were firstly pretreated in $\mathrm{O}_{2}(20 \mathrm{~mL} / \mathrm{min})$ for $30 \mathrm{~min}$ at $473 \mathrm{~K}, 573 \mathrm{~K}, 673 \mathrm{~K}, 773 \mathrm{~K}$, and $873 \mathrm{~K}$, respectively, and then reduced in $\mathrm{H}_{2}(20 \mathrm{~mL} / \mathrm{min})$ for another $30 \mathrm{~min}$. The reduction temperature was $473 \mathrm{~K}$ for the precursor pretreated in $\mathrm{O}_{2}$ at $473 \mathrm{~K}$ and $573 \mathrm{~K}$ for others. The catalysts pretreated in $\mathrm{O}_{2}$ at $673 \mathrm{~K}$ showed the best performance for $\mathrm{H}_{2} \mathrm{O}_{2}$ synthesis and only ca. 2\% leaching of the Pd loading after 5 hour reaction (Table S1).

Therefore, prior to the reaction, the precursors of all the catalysts were pretreated in $\mathrm{O}_{2}(20 \mathrm{~mL} / \mathrm{min})$ at $673 \mathrm{~K}$ for $30 \mathrm{~min}$ and then reduced in $\mathrm{H}_{2}(20 \mathrm{~mL} / \mathrm{min})$ at $573 \mathrm{~K}$ for another $30 \mathrm{~min}$. 


\subsection{Catalytic reaction}

All reactions were carried out under ambient conditions using a modified micro triphase semi-batch reactor. The reagent gases were introduced into the reactor via a premixer and a fine glass frit in sequence, and the slurry containing the catalyst was magnetically stirred to minimize diffusion limitations. The reactor was connected to a gas chromatograph so that the conversion of $\mathrm{H}_{2}$ could be determined on the basis of a standard curve indicating the quantitative relationship between the conversion of $\mathrm{H}_{2}$ and the $\mathrm{H}_{2} / \mathrm{N}_{2}$ area ratio. The conversion of $\mathrm{O}_{2}$ was also measured with an $\mathrm{O}_{2}$ balance of over $99 \%$. The concentration of $\mathrm{H}_{2} \mathrm{O}_{2}$ was analyzed calorimetrically using a UV-Vis spectrophotometer (Epp 2000, Stellar Net Inc.) after complexation with a $\mathrm{TiOSO}_{4} / \mathrm{H}_{2} \mathrm{SO}_{4}$ reagent. $\mathrm{H}_{2} \mathrm{O}_{2}$ selectivity, $\mathrm{S}_{\mathrm{H}_{2} 2}$, was calculated by Eq.(1):

$$
S_{\mathrm{H}_{2} \mathrm{O}_{2}}=\frac{r_{\mathrm{H}_{2} \mathrm{O}_{2}}(\mathrm{~mol} / \mathrm{h})}{r_{\mathrm{H}_{2}}(\mathrm{~mol} / \mathrm{h})} \times 100 \%=\frac{r_{\mathrm{H}_{2} \mathrm{O}_{2}}(\mathrm{~mol} / \mathrm{h})}{X_{\mathrm{H}_{2}} Q(\mathrm{~mol} / \mathrm{h})} \times 100 \%
$$

where $\mathrm{r}_{\mathrm{H}_{2} \mathrm{O} 2}$ is the mean rate of $\mathrm{H}_{2} \mathrm{O}_{2}$ formation calculated based on mol.s vs. time curves as in Fig. 1; $\mathrm{r}_{\mathrm{H} 2}$ is the mean rate of $\mathrm{H}_{2}$ consumption calculated based on $\mathrm{H}_{2}$ conversion $\left(\mathrm{X}_{\mathrm{H}_{2}}\right)$ and $\mathrm{H}_{2}$ flow rate $(\mathrm{Q}, 0.024 \mathrm{~mol} / \mathrm{h})$.

The reaction rate for $\mathrm{H}_{2} \mathrm{O}_{2}$ formation expressed in the turnover frequency (TOF, $\mathrm{h}^{-1}$ ) was obtained by Eq.(2):

$$
r_{\mathrm{H}_{2} \mathrm{O}_{2}, \mathrm{TOF}}=\frac{r_{\mathrm{H}_{2} \mathrm{O}_{2}, n_{\mathrm{Pd}}}}{D_{\text {particle }}}=\frac{r_{\mathrm{H}_{2} \mathrm{O}_{2}} / n_{P d}}{D_{\text {particle }}}
$$

where $\mathrm{r}_{\mathrm{H}_{2} \mathrm{O}_{2} \text {, ned }}$ is the mean rate of $\mathrm{H}_{2} \mathrm{O}_{2}$ formation $\left(\mathrm{r}_{\mathrm{H}_{2} 2}, \mathrm{~mol} / \mathrm{h}\right)$ per unit amount of $\mathrm{Pd}$ calculated based on the total amount of $\mathrm{Pd}\left(\mathrm{n}_{\mathrm{Pd}}, \mathrm{mol}\right)$, and $\mathrm{D}_{\text {particle }}$ is the dispersion of 
metal atoms (Eq.(3)) exposure to reactants evaluated on the basis of a hemispheric model:

$$
D=6 \frac{v_{m} / a_{m}}{d_{V A}}
$$

where $\mathrm{v}_{\mathrm{m}}\left(1.47 \times 10^{-23} \mathrm{~cm}^{3}\right)$ is the volume occupied by a Pd atom in the bulk of Pd metal, which is given by $\mathrm{v}_{\mathrm{m}}=\mathrm{M} /\left(\rho \mathrm{N}_{\mathrm{A}}\right)$, where $\mathrm{M}(106.42 \mathrm{~g} / \mathrm{mol})$ is the atomic mass of $\mathrm{Pd}, \rho\left(12.02 \mathrm{~g} / \mathrm{cm}^{3}\right)$ is the mass density and $\mathrm{N}_{\mathrm{A}}\left(6.022 \times 10^{23} \mathrm{~mol}^{-1}\right)$ is Avogadro's number; $\mathrm{a}_{\mathrm{m}}\left(7.93 \times 10^{-16} \mathrm{~cm}^{2}\right)$ is the surface area occupied by a Pd atom on a polycrystalline surface, given by $a_{m}=1 / n_{s}$, where $n_{s}$ is the number of atoms per unit area in the crystalline planes; and $\mathrm{d}_{\mathrm{VA}}$ is the volume-area mean diameter or mean particle size obtained from TEM.

In the reaction, an $\mathrm{O}_{2}: \mathrm{H}_{2}: \mathrm{N}_{2}=36: 9: 15$ gas mixture with a flowrate of $60 \mathrm{~mL} / \mathrm{min}$ was introduced into the reaction system at $283.15 \mathrm{~K}$ without special statement. The liquid phase was composed of $60 \mathrm{~mL}$ of ethanol that had been acidified with $0.38 \mathrm{~mL}$ of concentrated $\mathrm{H}_{2} \mathrm{SO}_{4}$. Following each experiment, residual $\mathrm{Pd}$ that had been deposited on the frit was removed by ultrasonic cleaning with acidic solution and ultrapure water. In most cases, a yellow-orange solution, resulting from $\mathrm{Pd}^{2+}$, was observed.

Since the gas mixture is still in the explosive regime, care must be taken to avoid contact of the gas mixture with a dry catalyst. This was achieved first by mixing 50 mg of the catalyst with $10 \mathrm{~mL}$ of the solution; and then, the slurry was added back into the solution that remained in the reactor. It should be noted that with ethanol as the liquid phase the catalyst remained wet, even in the upper regions of the reactor. 50 
143

144

145

146

147

148

149

150

151

152

153

154

mg of catalysts was used for all tests. Further information about experiments has been given in SI.

\subsection{Characterizations}

A series of characterization methods were used to determine the structure of Pd/HAp catalysts. Ahead of measurements, catalysts were pretreated following the same method used in reactions. All precursors were pretreated in $\mathrm{O}_{2}(20 \mathrm{~mL} / \mathrm{min})$ at $673 \mathrm{~K}$ for $30 \mathrm{~min}$ and then reduced in $\mathrm{H}_{2}(20 \mathrm{~mL} / \mathrm{min})$ at $573 \mathrm{~K}$ for another $30 \mathrm{~min}$. All samples were protected to avoid the exposure to air before measurements.

Transmission electron microscopy (TEM) measurements were performed on a JEOL JEM 2010F electron microscope operating at $200 \mathrm{kV}$. The catalysts were first ultrasonically suspended in ethanol, and then one drop of this slurry was deposited on a carbon-coated copper grid. The liquid phase was evaporated before the grid was loaded into the microscope. The size distribution of Pd particles was estimated on the basis of 300 particles.

The Aberration-corrected scanning transmission electron microscopy (STEM) measurements were performed on a FEI Titan 80-300 electron microscope. The STEM resolution is $0.136 \mathrm{~nm}$ with the accelerating voltage of $300 \mathrm{kV}$, and the energy resolution of Tridem Gatan Electron Energy Loss Spectroscopy (EELS) system is 0.7 $\mathrm{eV}$.

X-ray diffraction (XRD) patterns were recorded using a Rigaku D/max 2550 diffractometer, with accelerating voltage $40 \mathrm{kV}$, and detector current $100 \mathrm{~mA} . \mathrm{Cu}-\mathrm{K}$ radiation was used for continuous scanning with a step-size of $0.02^{\circ}$ over a $2 \theta$ range 
of $10^{\circ}-80^{\circ}$ with a scan speed of $4^{\circ} / \mathrm{min}$.

X-ray photoelectron spectroscopy (XPS) analysis was performed on a Thermo ESCALAB 250Xi spectrometer, using a monochromatic Al-K radiation source (1486.6 eV, a pass energy of $20.0 \mathrm{eV}$ ). The base pressure of the instrument is about $1 \times 10^{-9}$ Torr. The binding energies (BEs) were calibrated using the $\mathrm{C} 1 \mathrm{~s}$ peak at 284.8 $\mathrm{eV}$ as a reference. The instrument was also calibrated using $\mathrm{Au}$ wire (Au4f $7 / 2$ at 84.0 $\mathrm{eV}$ ). The background of XP spectra caused by inelastic processes was subtracted by the Shirley method.

The extended X-ray absorption fine structure (EXAFS) and X-ray absorption near-edge structure (XANES) spectra of the Pd K edge were measured at the BL14W1 beamline, Shanghai Synchrotron Radiation Facility (SSRF), with electron beam energy of $3.5 \mathrm{GeV}$ under "top-up" mode (current: $220 \mathrm{~mA}$ ). The samples were measured at room temperature using a fixed-exit monochromator equipped with two flat $\mathrm{Si}(311)$ crystals. Data on the catalysts and reference samples (Pd foil and PdO powder) were collected in the fluorescence mode (32-element HPGe detector) or the transmission mode (Oxford ion chamber). Athena and Artemis softwares were used to extract the data and to fit the curves, respectively [42, 43]. The Fourier-transformed curves were fitted in the real space with $\Delta \mathrm{k}=2-13 \AA^{-1}$ and $\Delta \mathrm{R}=1.1-3.3 \AA$ for $\mathrm{Pd}$ ( $k^{2}$ weighted).

Diffuse reflectance infrared fourier transform spectroscopy of $\mathrm{CO}$ adsorption (CO-DRIFTS) on the fresh catalysts was conducted in a reaction cell (modified Harricks Model HV-DR2) in order to allow gas to flow continuously through the 
catalyst bed (ca. $0.1 \mathrm{~g}$ ) during spectra acquisition. The spectra were recorded on a Perkin-Elmer Spectrum 100 FT-IR spectrometer at 283.15 K with a resolution of 4 $\mathrm{cm}^{-1}$. All infrared data were evaluated in Kubelka-Munk units, which are linearly related to the absorber concentration in spectra.

Temperature-programmed desorption (TPD) experiments were performed with a micro fixed-bed reactor connected to a GC-QMS (HPR-20, Hiden Analytical Ltd.), where masses of m/e $2\left(\mathrm{H}_{2}\right), 15\left(\mathrm{CH}_{4}\right), 18\left(\mathrm{H}_{2} \mathrm{O}\right), 32\left(\mathrm{O}_{2}\right), 40(\mathrm{Ar})$, and $44\left(\mathrm{CO}_{2}\right)$ were monitored.

In order to further detect the residual $\mathrm{Cl}^{-}$on the catalyst, $0.5 \mathrm{~g}$ catalyst powder was treated by microwave digestion, and the solution was tested by an ion chromatograph (ICS-2000, Dionex, USA), which was equipped with an IonPac AG18 + AS18 column. $\mathrm{KOH}(5 \mathrm{mM})$ was used as the mobile phase.

\subsection{Computational models and methods}

DFT calculations were performed using the Vienna ab-initio simulation package (VASP) [44, 45]. A plane-wave basis set with a cut-off energy of $400 \mathrm{eV}$ was used to expand the Kohn-Sham wave functions. The interactions between the ionic cores and valence electrons were described using a projector augmented wave (PAW) method $[46,47]$, and the exchange-correlation effects were self-consistently described within the Perdew-Burke-Ernzerh of generalized gradient approximation (GGA-PBE) [48, 49]. The occupation of electronic states was determined using Gaussian smearing (the Methfessel-Paxton method [50] for Pd(111) model), and the smearing width was 0.2 eV. Optimized geometries were obtained by minimizing the root mean square (rms) 
forces on the atoms until they are smaller than $0.05 \mathrm{eV} / \mathrm{A}$.

$\mathrm{Pd}_{1} / \mathrm{HAp}, \mathrm{Pd}_{3} / \mathrm{HAp}$ and $\mathrm{Pd}_{10} / \mathrm{HAp}$ models were built to simulate the Pd single sites and the Pd clusters supported on the HAp surface, and $\mathrm{Pd}_{3}$ and $\mathrm{Pd}_{10}$ models were built to simulate the pure Pd clusters for the reference. $\mathrm{Pd}(111)$ was adopt to model relatively large $\mathrm{Pd}$ particles $[32,36,51,52]$. For $\mathrm{Pd}_{3}$ and $\mathrm{Pd}_{10}$ models, a $15 \times 15 \times 15 \AA^{3}$ cubic supercell was adopted to avoid interactions between adjacent periodic images, and the Brillouin zone was sampled with the Gamma point only. HAp was modeled by a half-layered $(100)$ slab with a $(1 \times 2)$ unit cell. All Pd atoms, reactants, and the topmost fraction layer of HAp were relaxed. The calculated lattice constants for HAp are $\mathrm{a}=9.424 \AA$ and $\mathrm{c} / \mathrm{a}=0.730$. Some possible positions of the Pd clusters with respect to $\operatorname{HAp}(100)$ were tested to identify the most stable structure. $\operatorname{Pd}(111)$ was modeled as a four-layered slab with a $(3 \times 3)$ unit cell, of which the topmost two layers were relaxed. A vacuum spacing of $12 \AA$ along the normal direction (z) to the surface and a $3 \times 3 \times 1$ Monk horst-Pack $k$-point mesh were used for the Pd clusters on HAp and $\operatorname{Pd}(111)$. All transition states were found using the climbing image nudged elastic band (NEB) method [53] and confirmed via vibrational analysis.

The reaction energies $(\Delta E)$ of each elementary step were calculated by Eq.(4):

$$
\Delta E=E_{F S}-E_{I S}
$$

$E_{\mathrm{FS}}$ and $E_{\mathrm{IS}}$ are the total energies of the final state (FS) and initial state (IS) of the minimum-energy path (MEP), respectively. The activation barriers $\left(E_{\mathrm{a}}\right)$ of the elementary steps were calculated by Eq. (5):

$$
E_{a}=E_{T S}-E_{I S}
$$

$E_{\mathrm{TS}}$ is the energy of the transition state (TS) of MEP. The zero point energy (ZPE) 
correction is included into the reaction energy and activation barrier as Eq. (6):

$$
Z P E=\sum_{i}^{\# v i b s}\left(\frac{1}{2}\right) \mathrm{hv}_{i}
$$

where $\mathrm{h}$ and $v_{i}$ are Planck constant and the calculated vibrational frequencies, respectively.

\subsection{Reaction constants and equilibrium constants}

237 Reaction constants and equilibrium constants of the dissociation of $\mathrm{O}_{2}$ and the formation of $\mathrm{OOH}$ were calculated with statistical treatment of results of DFT calculations (Table S2). The rate constant $(k)$ in Eq.(7) is defined in terms of transition state theory (TST) [54]:

$$
k=\frac{k_{B} T}{h} \exp \left(\frac{-\Delta G_{a}}{k_{B} T}\right)
$$

242 Where $k_{B}$ and $T$ represent the Boltzmann factor and reaction temperature, respectively. was consistent with that for experiments.

$\Delta G_{a}$ is the change of the standard molar Gibbs free energy between transition state (TS) and initial state (IS) of elementary steps. The reaction temperature, $\mathrm{T}=283.15 \mathrm{~K}$,

$$
K=\exp \left(\frac{-\Delta G}{k_{B} T}\right)
$$

$\Delta G$ is the change of the standard molar Gibbs free energy between the final state (FS) and the initial state (IS) of elementary steps.

The Gibb's free energies of all surface intermediates were calculated by Eq. (9):

$$
G(\mathrm{~T})=E_{D F T}+Z P E+\int_{0}^{T} C_{V, \text { vib }} d T-T \cdot S(\mathrm{~T})
$$

Where $E_{D F T}, C_{V, v i b}$, and $S(T)$ are the total energy from DFT calculation, heat capacity, 


$$
R_{A}=\frac{k_{O O H}}{k_{O_{2}}}
$$

$$
R_{B}=\frac{K_{O O H}}{K_{O_{2}}}
$$

272 following Eqs. (12-13) [35, 55]:

$$
\mathrm{O}_{2} * * \rightarrow 2 \mathrm{O}^{*}
$$
$\mathrm{Pd} / \mathrm{HAp}$ catalysts.

gaseous molecule was considered to involve the two elementary steps. Therefore, $\Delta G_{a}$ and $\Delta G$ can be calculated by Eqs (10-11):

$$
\begin{gathered}
\Delta G_{a}=E_{a}+\left(Z P E_{T S}-Z P E_{I S}\right)+\left[\left(\int_{0}^{T} C_{V, \mathrm{vib}} d T\right)_{T S}-\left(\int_{0}^{T} C_{V, \mathrm{vib}} d T\right)_{I S}\right]-T \cdot\left[S(\mathrm{~T})_{T S}-S(\mathrm{~T})_{I S}\right] \\
\Delta G=\Delta E+\left(Z P E_{F S}-Z P E_{I S}\right)+\left[\left(\int_{0}^{T} C_{V, \mathrm{vib}} d T\right)_{F S}-\left(\int_{0}^{T} C_{V, \mathrm{vib}} d T\right)_{I S}\right]-T \cdot\left[S(\mathrm{~T})_{F S}-S(\mathrm{~T})_{I S}\right]
\end{gathered}
$$

The corrections of entropy, $S(T)$, and the heat capacity, $C_{V, v i b}$, are evaluated

$$
S(\mathrm{~T})=k_{B} \sum_{i}^{\# v i b s}\left[\frac{h v_{i}}{k_{B} T\left(\mathrm{e}^{\frac{h v_{i} T}{k_{B} T}}-1\right)}-\ln \left(1-\mathrm{e}^{\frac{-h v_{i}}{k_{B} T}}\right)\right]
$$

The dissociation of $\mathrm{O}_{2}$ is defined as Eq. (14):

The formation of $\mathrm{OOH}$ is defined as Eq. (15):

$$
\mathrm{O}_{2}^{*}+\mathrm{H}^{*} \rightarrow \mathrm{OOH}^{*}+*
$$

Two descriptors, the ratio of the rate constant of $\mathrm{OOH}$ formation to that of $\mathrm{O}_{2}$ dissociation ( $\mathrm{R}_{\mathrm{A}}$, Eq. (16)) and the ratio of equilibrium constant of $\mathrm{OOH}$ formation to that of $\mathrm{O}_{2}$ dissociation $\left(\mathrm{R}_{\mathrm{B}}\right.$, Eq. (17)), are defined here to evaluate the performance of

Where $k_{O O H}$ and $K_{O O H}$ are rate constant and equilibrium constant of the $\mathrm{OOH}$ 
273

274

formation; $k_{O_{2}}$ and $K_{O_{2}}$ are rate constant and equilibrium constant of the $\mathrm{O}_{2}$ dissociation.

\section{Results and discussion}

\subsection{Catalytic performance}

As shown in Fig. 1 and Table 1, no $\mathrm{H}_{2}$ conversion was measured for the catalyst prepared by Pd(I.E.). A selectivity of $94 \%$ and a rate of $284 \mathrm{~h}^{-1}$ were determined for $0.5 \mathrm{wt} \% \mathrm{Pd}$. Such a high selectivity achieved over a Pd alone catalyst without any promoter, to the best of our knowledge, has been rarely reported so far. With increasing the Pd loading, the rate was increased to $340 \mathrm{~h}^{-1}$, while the selectivity dropped down to $67 \%$ over $1.0 \mathrm{wt} \% \mathrm{Pd}$, continuously decreased to $197 \mathrm{~h}^{-1}$ and $43 \%$ over $5.0 \mathrm{wt} \%$ Pd. Obviously, both the selectivity and rate of Pd catalysts depend highly on the Pd loading.

Meanwhile, the effect of contact time (due to the change of the Pd loading) on $\mathrm{H}_{2} \mathrm{O}_{2}$ selectivity had also been ruled out by well-designed experiments (Table S3). Moreover, the potential effect from the leached $\mathrm{Pd}$ and residual $\mathrm{Cl}^{-}$were investigated, of which the influences were hardly detectable on the reaction, as listed in Table S3 and S4.

\subsection{Size distribution and morphology of Pd particles}

XRD patterns showed that the framework of HAp was rather stable during the preparation process (Fig. 2). In the meantime, almost no diffraction peak of Pd crystalline can be determined for $0.5 \mathrm{wt} \%$ and $1.0 \mathrm{wt} \%$ Pd catalysts, suggesting that the size of Pd particles are no larger than $3.0 \mathrm{~nm}$ (a limit for XRD analysis). A small 
peak at $40.1^{\circ}$, assigned to the $\operatorname{Pd}(111)$ plane, emerged with the increasing of the $\mathrm{Pd}$ loading from 2.0 to $5.0 \mathrm{wt} \%$. The same tendency was also revealed by BF-TEM images (Fig. 3). The size of Pd particles was estimated to be ca. $1.6 \mathrm{~nm}$ for $0.5 \mathrm{wt} \%$ $\mathrm{Pd}$, and increased to ca. $2.6 \mathrm{~nm}$ for $5.0 \mathrm{wt} \% \mathrm{Pd}$; meanwhile, ca. $1.4 \mathrm{~nm}$ for $0.5 \mathrm{wt} \%$ Pd was observed using the annular dark-field TEM (ADF-TEM) (Fig. 3F). Notably, after 2 hour reaction, the average size of $0.5 \mathrm{wt} \% \mathrm{Pd}$ and $5 \mathrm{wt} \% \mathrm{Pd}$ catalysts changed to ca. $1.8 \mathrm{~nm}$ and $3.1 \mathrm{~nm}$, respectively (Fig. S2). We deduce that catalytic reactions would enhance the mobility of Pd particles on the HAp surface, thus lead to a mild aggregation. A typical chemical composition for $1.0 \mathrm{wt} \%$ Pd was identified by EDS as well (Fig. S3).

Taking a close look at those particles by STEM (Fig. 3H), we did not observe any clear-cut crystal-facet or quasi-crystal Pd phase, while spherical Pd particles were randomly stacked on the HAp surface. Smaller Pd particles were further determined using EXAFS, the data was analyzed following the procedure in Figures S4-S6. As shown in Fig. 4 and Table 2, there was no measurable Pd-Pd bond for Pd(I.E.), indicating that mono-dispersed or isolated $\mathrm{Pd}$ atoms were predominant on the surface [56]. For $0.5 \mathrm{wt} \% \mathrm{Pd}$, there exists a Pd-O bond of $2.11 \pm 0.03 \AA$ and a Pd-Pd bond of $2.80 \pm 0.03 \AA$ with acoordination number $(\mathrm{CN})$ of $1.1 \pm 0.6$, suggesting that the $\mathrm{Pd}$ clusters with 2-3 Pd atoms can be stabilized on HAp. With the combination of EXAFS with TEM results, we assume three types of Pd particles in 0.5 wt $\% \mathrm{Pd}$ : mono-dispersed Pd atoms (zero-dimension (0D)), subnano Pd clusters with a few Pd atoms (two- or three-dimensions (2D or 3D)) and Pd nanoparticles with crystalline 
phase (three-dimension (3D)). The low $\mathrm{CN}$ of the $\mathrm{Pd}-\mathrm{Pd}$ bond hints that mono-dispersed $\mathrm{Pd}$ atoms and $\mathrm{Pd}$ clusters are the dominant active species for 0.5 wt $\% \mathrm{Pd}$, of which the size of Pd particles should be even less than $1.4 \mathrm{~nm}$ with considering the detection limit of TEM. determined. The Pd-Pd bond of $2.74 \pm 0.04 \AA$, close to the Pd-Pd distance in Pd of mono-dispersed Pd atoms (0D) and subnano Pd clusters (2D or 3D). investigate the size effects on the catalytic performance, we further synthesized two 
found that the selectivity was unaffected with increasing the particle size above 2.5 $\mathrm{nm}$. This issue will be further discussed later.

On the other hand, in situ Infrared (IR) spectra (Fig. S7) revealed a decrease in the intensity of the characteristic peak of $\mathrm{OH}$ in $\mathrm{HAp}\left(3574 \mathrm{~cm}^{-1}\right)$ with the rise of $\mathrm{Pd}$ loading. This fact indicates that the cleavage of $\mathrm{OH}$ is induced by $\mathrm{Pd}$ atoms through forming a Pd-O bond, which is supposed to stabilize Pd particles.

\subsection{Electronic structure of Pd particles}

The electronic structure of the surface Pd atoms was characterized by in situ CO-DRIFT spectra (Fig. 5). The decrease in Pd particle size led to a rise in the linear CO adsorbed on atop sites $\left(2091 \mathrm{~cm}^{-1}\right)$, while the number of $\mathrm{CO}$ adsorbed on bridged (1988 1964 $\left.\mathrm{cm}^{-1}\right)$ and three-fold $\left(1913 \sim 1873 \mathrm{~cm}^{-1}\right)$ sites decreased gradually $[57,58]$. It is noted that there is no vibrational band for both HAp and Pd(I.E.) catalysts, so that we can safely exclude any signals from support, while the number of isolated Pd atoms is perhaps too small to yield vibrational band for the latter. The linear band at $2091 \mathrm{~cm}^{-1}$ detected for $0.5 \sim 2.0 \mathrm{wt} \%$ Pd catalysts indicates the formation of the highly dispersed metallic Pd atoms and clusters, corresponding to $0 \mathrm{D}$ and 2D particles; the band intensity remained unchanged with the rise in the Pd loading, we infer the formation of subnano particles is primarily affected by the local environment on the HAp surface. In the meantime, the several bridged bands appeared for 0.5 wt $\% \mathrm{Pd}$ and their intensities increased with the Pd loading, which hints the production of tightly compacted Pd clusters or larger Pd particles in 3D. In particular, the growing bands (1913-1873 $\mathrm{cm}^{-1}$ ) assigned to hollow sites indicate more adsorption sites 
composed of high density of Pd atoms. Furthermore, the linear band disappeared completely for $3.0 \mathrm{wt} \%$ and $5.0 \mathrm{wt} \% \mathrm{Pd}$, which might suggest that the subnano Pd particles in $0 \mathrm{D}$ and 2D unlikely exist for both catalysts, due to the feasible coalescence of Pd particles during the preparation process.

XPS spectra (Fig. 6) show the different oxidation states of the Pd surface atoms. Only weak signals for the 0.5 wt \% Pd catalyst exist because of the low concentration of $\mathrm{Pd}$ atoms. The metallic $\mathrm{Pd}\left(\mathrm{Pd} 3 \mathrm{~d}_{5 / 2}=335.5 \mathrm{eV}\right)$ was the predominant species for both 5 wt $\% \mathrm{Pd}$ and 3 wt $\% \mathrm{Pd}$; the upshift of the BE of Pd $3 \mathrm{~d}_{5 / 2}$ from $335.5 \mathrm{eV}$ (5 wt \% Pd, $\mathrm{d}_{\mathrm{Pd}}:$ ca. $\left.2.6 \mathrm{~nm}\right)$ to $336.5 \mathrm{eV}\left(0.5 \mathrm{wt} \% \mathrm{Pd}, \mathrm{d}_{\mathrm{Pd}}:\right.$ ca. $\left.1.4 \mathrm{~nm}\right)$ was measured as well. On the basis of those results, we propose a surface transformation from $\mathrm{Pd}^{0}$ to $\mathrm{Pd}^{\delta+}$ with the decreasing of Pd particle size in the subnano range. The oxidation of surface Pd atoms on supported catalysts has proven to be prone at room temperature with the strong metal support interaction [59]. Herein, we propose that the generation of $\mathrm{Pd}^{\delta+}$ comes from the reaction between Pd and hydroxyls of HAp.

The formation of $\mathrm{PdO}_{\mathrm{x}}$ was further evidenced by $\mathrm{O}_{2}$-TPD profiles (Fig. 7). Strong peaks in the region of 777-900 $\mathrm{K}$ can be assigned to atomic oxygen resulting from the decomposition of $\mathrm{PdO}_{\mathrm{x}}$ [60-65], because the desorption temperatures of dioxygen are usually lower than $600 \mathrm{~K}$. It was reported on a $\mathrm{Pd} / \mathrm{SiO}_{2}$ catalyst that bulk $\mathrm{PdO}_{\mathrm{x}}$ cannot be formed until $623 \mathrm{~K}$ [66], indicating that the influence of exposure to air at room temperature should be trivial. Therefore, the peak of $\mathrm{PdO}_{\mathrm{x}}$ may result from the reaction between $\mathrm{Pd}$ and the hydroxyls of HAp with the increase in temperature during the TPD test. It suggests that HAp has significant promotional effects on the 
oxidation of Pd nanoparticles. The peaks centered at $373 \mathrm{~K}$ and $573 \mathrm{~K}$ can be contributed by the surface adsorbed oxygen species on Pd particles. The decrease in the Pd loading could reduce the atomic oxygen, but increase adsorbed dioxygen, it is in line with the analysis of EXAFS.

\subsection{The structure models of active sites}

In order to get deep insights into the size effects on the catalytic performance, we simulated the structure of active sites in Pd particles by DFT calculations. A series of models for active sites (Fig. 8) were proposed: mono-dispersed single Pd sites (0D), subnano Pd clusters (2D or 3D) and Pd nanoparticles with crystalline phase (3D).

$\mathrm{H}_{2} \mathrm{O}_{2}$ is produced by sequential hydrogenation of $\mathrm{O}_{2}$ on the surface, while $\mathrm{H}_{2} \mathrm{O}$ is formed by O-O bond rupture within surface species containing O-O bond [67]. The formation of $\mathrm{OOH}$ and the dissociation of $\mathrm{O}_{2}$ are key elementary steps for $\mathrm{H}_{2} \mathrm{O}_{2}$ synthesis, being responsible to the formation of $\mathrm{H}_{2} \mathrm{O}_{2}$ and $\mathrm{H}_{2} \mathrm{O}$, respectively. The selectivity toward $\mathrm{H}_{2} \mathrm{O}_{2}$ is therefore mainly determined by the competitive reactions between the $\mathrm{O}-\mathrm{H}$ bond formation and the $\mathrm{O}-\mathrm{O}$ bond cleavage. In order to evaluate the $\mathrm{H}_{2} \mathrm{O}_{2}$ selectivity over $\mathrm{Pd} / \mathrm{HAp}$ models, two descriptors, $\mathrm{R}_{\mathrm{A}}$ (the ratio of the rate constants for $\mathrm{OOH}$ formation and $\mathrm{O}_{2}$ dissociation) and $\mathrm{R}_{\mathrm{B}}$ (the ratio of equilibrium constants for $\mathrm{OOH}$ formation and $\mathrm{O}_{2}$ dissociation), were calculated.

As listed in Table $\mathrm{S} 2, \mathrm{Pd}_{10} / \mathrm{HAp}$ shows the highest $\mathrm{R}_{\mathrm{A}}$ and $\mathrm{R}_{\mathrm{B}}$ values $\left(\log \left(\mathrm{R}_{\mathrm{A}}\right)=\right.$ 5.36, $\log \left(R_{B}\right)=11.06$ ), while $\log \left(R_{A}\right)=2.60$ and $\log \left(R_{B}\right)=7.30$ were found for $\mathrm{Pd}_{3} /$ HAp. $\mathrm{Pd}(111)$ presents lower $\mathrm{R}_{\mathrm{A}}$ and $\mathrm{R}_{\mathrm{B}}$ values $\left(\log \left(\mathrm{R}_{\mathrm{A}}\right)=-0.31, \log \left(\mathrm{R}_{\mathrm{B}}\right)=-25.60\right)$ as shown in Fig. $8 \mathrm{E}$ and Table $\mathrm{S} 2$. For $\mathrm{Pd}_{1} / \mathrm{HAp}$, it suggests that the adsorption of $\mathrm{H}_{2}$ 
405

406

407

is unfavorable on the single $\mathrm{Pd}$ site (Table S5), which hinders the subsequent $\mathrm{H}_{2} \mathrm{O}_{2}$ synthesis. It explains the inertness of $\mathrm{Pd}\left(\mathrm{I}\right.$.E.) for $\mathrm{H}_{2} \mathrm{O}_{2}$ synthesis. The $\mathrm{H}_{2} \mathrm{O}_{2}$ selectivity over pure $\mathrm{Pd}_{3}$ cluster $\left(\log \left(\mathrm{R}_{\mathrm{A}}\right)=-13.14, \log \left(\mathrm{R}_{\mathrm{B}}\right)=-44.82\right)$ is much lower than that for $\mathrm{Pd}_{3} /$ HAp $\left(\log \left(\mathrm{R}_{\mathrm{A}}\right)=2.60, \log \left(\mathrm{R}_{\mathrm{B}}\right)=7.30\right)$. The $\mathrm{Pd}_{10}$ cluster also showed an inferior performance $\left(\log \left(\mathrm{R}_{\mathrm{A}}\right)=-7.34, \log \left(\mathrm{R}_{\mathrm{B}}\right)=-24.36\right)$ compared with $\mathrm{Pd}_{10} / \mathrm{HAp}\left(\log \left(\mathrm{R}_{\mathrm{A}}\right)=\right.$ 5.36, $\left.\log \left(\mathrm{R}_{\mathrm{B}}\right)=11.06\right)$. The selectivities over different Pd particles follow an order as: 3D Pd clusters $>2 \mathrm{D}$ Pd clusters $>$ larger Pd particles $(>2.5 \mathrm{~nm})$. It is understandable that $0.5 \mathrm{wt} \% \mathrm{Pd}$, which is abundant with subnano particles, shows the highest selectivity among all catalysts.

\subsection{Structure-performance relationship}

$\mathrm{H}_{2} \mathrm{O}_{2}$ has proven to be formed on metallic $\mathrm{Pd}$ with geometric and electronic modification by additives, such as chlorine, bromide, and oxygen or nitrogen from the support [26, 33, 39, 68, 69]. However, size effects of $\mathrm{Pd}$ particles on $\mathrm{H}_{2} \mathrm{O}_{2}$ synthesis have rarely been reported [25]. With the combination of experiments and DFT calculations, we here envisage a structure-performance relationship by the variation of the Pd particle size.

On the basis of Pd particle sizes and catalytic performance, the catalysts studied in this work can be classified into three types (Fig. 9). The first type ( $\operatorname{Pd}(\operatorname{I.E})$.$) is$ predominantly composed of mono-dispersed Pd atoms as evidenced by EXAFS, showing an extremely low activity due to the lack of active sites, even though single site catalysts have proven to be active for other reactions $[9,11]$.

The second type $(0.5 \sim 2.0 \mathrm{wt} \% \mathrm{Pd})$, of which the average size of $\mathrm{Pd}$ particles 
ranges from $1.4 \mathrm{~nm}$ to $2.5 \mathrm{~nm}$, mainly consists of $2 \mathrm{D}$ and $3 \mathrm{D}$ Pd clusters, being responsible for $\mathrm{H}_{2} \mathrm{O}_{2}$ synthesis as identified by DFT calculations. Again, those results have proved an assertion on this reaction system: the configuration of surface $\mathrm{Pd}$ atoms is one of decisive factors affecting the catalytic activities [33]. Furthermore, as listed in Table 1, the structure of active sites should be modified by changing the Pd particle size in the range of $1.4 \sim 2.5 \mathrm{~nm}$ because the selectivity toward $\mathrm{H}_{2} \mathrm{O}_{2}$ could be significantly enhanced with the decrease in Pd particle size.

The third type (3.0 5.0 wt \% Pd) mainly consists of large nanoparticles (>2.5 nm) with abundant of $\mathrm{Pd}(111)$ facets, which are not favorable for the formation of $\mathrm{H}_{2} \mathrm{O}_{2}$, because the metallic $\mathrm{Pd}$ are rather active for the $\mathrm{O}_{2}$ dissociative activation, thus leading to the formation of $\mathrm{H}_{2} \mathrm{O}$. The dissociation of $\mathrm{O}_{2}$ was detected at $200 \mathrm{~K}$ on the (111) facet of model Pd catalysts, and the temperature could be even lower at step and corner sites $[64,70]$. It should be emphasized here that the surface configuration of Pd atoms is not unique but one of the key factors influencing the structure of active sites for $\mathrm{H}_{2} \mathrm{O}_{2}$ synthesis.

As mentioned above, we thus get a deep understanding of the Pd size effects and its structure-performance relationship for $\mathrm{H}_{2} \mathrm{O}_{2}$ synthesis. The significant effect of HAp resulted in a relatively narrow size distribution of $\mathrm{Pd}$ particles with average sizes ranging from ca. $1.4 \mathrm{~nm}$ to ca. $30 \mathrm{~nm}$, leading to different geometric and electronic structures of $\mathrm{Pd}$ particles. In particular, a relatively high ratio of $\mathrm{Pd}^{\delta+} / \mathrm{Pd}^{0}$ resulted from the reaction between Pd and hydroxyls from HAp in subnano Pd particles should be the primary reason for the remarkable improvement of $\mathrm{H}_{2} \mathrm{O}_{2}$ selectivity. $\mathrm{Pd}^{\delta+}$ in 
449

450

451

452

453

454

455

456

457

458

459

460

461

462

463

464

465

466

467

468

469

470

catalysts has proved to reduce the dissociative activation of $\mathrm{O}_{2}$ and the decomposition of $\mathrm{H}_{2} \mathrm{O}_{2}[33,71]$. In addition, the contraction of Pd lattice in subnano clusters with the decrease in size would lead to a concomitant weakening of chemisorptive interaction of $\mathrm{O}_{2}$ and catalysts [72]. As a result, the $\mathrm{Pd}$ particles with the size of $1.4 \mathrm{~nm}$ (ADF-TEM) showed the maximum selectivity of $94 \%$ toward $\mathrm{H}_{2} \mathrm{O}_{2}$.

By this case study, we recognize that metal particles in subnano size are not only strongly anchored on technical catalysts, but also act as primary active sites. The structure of metal catalysts, especially the electronic structure and the chemical environment in the surface of metal particles, can be finely tailored through the control of particle size down to subnano level. At least, this work here reveals that the so-called "smaller is better" for catalysts could only be applied in a certain size range.

Nevertheless, the dynamic structure of $\mathrm{PdO}_{\mathrm{x}} / \mathrm{Pd}$ interfaces during the reaction is still far from clear; the effects of HAp on the formation of Pd particles are not studied; the activity still need to be improved significantly while ensuring the high selectivity remains. In particular, the effects of dimensional constrains on the catalytic performance of $\mathrm{Pd}$ catalysts is still ambiguous. The development of advanced separation techniques is needed to avoid excessive accumulation of $\mathrm{H}_{2} \mathrm{O}_{2}$ on the catalyst surface during the reaction, which can further improve the stability of the catalysts. The relevant studies are of great significance for the design of industrial catalysts.

\section{Conclusions}

As characterized by multi-techniques and experiments, size effects of Pd particles on 
471

472

473

474

475

476

477

478

479

480

481

482

483

484

485

486

487

488

489

490

491

492

the catalytic performance of $\mathrm{H}_{2} \mathrm{O}_{2}$ synthesis has been demonstrated, and the selectivity toward $\mathrm{H}_{2} \mathrm{O}_{2}$ formation has found to be improved with the decrease in $\mathrm{Pd}$ particle size in the range of $2.5 \sim 1.4 \mathrm{~nm}$, which reached to ca. $94 \%$ over $0.5 \mathrm{wt} \% \mathrm{Pd}$ $\left(\mathrm{d}_{\mathrm{Pd}}: \sim 1.4 \mathrm{~nm}\right)$. In contrast, the single site catalyst $(\mathrm{Pd}(\mathrm{I}$.E. $))$ is inactive. The selectivity to $\mathrm{H}_{2} \mathrm{O}_{2}$ remained nearly unchanged with increasing the Pd particle size from $2.5 \mathrm{~nm}$ to $30 \mathrm{~nm}$.

In the subnano size range, the Pd particles composed of OD (Pd(I.E.)), 2D (0.5 2.0 wt \% Pd) and 3D (0.5 5.0 wt \% Pd) were observed, as identified by XRD, HRTEM and EXAFS. In the meantime, as demonstrated by XPS, in situ CO-DRIFTS and $\mathrm{O}_{2}$-TPD, the electronic structure of $\mathrm{Pd}$ surface can be tailored with varying the particle size. Especially, higher ratios of surface Pd atoms have found to be positively charged and formed $\mathrm{PdO}_{\mathrm{x}} / \mathrm{Pd}$ interfaces on subnano sized particles. The surface $\mathrm{Pd}^{\delta+}$ could suppress the unexpected dissociative adsorption of dioxygen, which leads to the over-oxidation of $\mathrm{H}_{2}$ to $\mathrm{H}_{2} \mathrm{O}$.

The origin of the particle size effects have been further illustrated by modeling the structures of Pd active sites using DFT calculations. Among all models, $\mathrm{Pd}_{10} / \mathrm{HAp}$ has found to be the optimal structure for this reaction, and subnano clusters possess the best catalytic performance. It agrees well with the experimental results. We have demonstrated that the smaller may not be better, while excellent catalytic performances could be obtained by finely optimizing the particle size in a certain range. 
494 The authors are grateful to the support from the National Science Foundation 495 (21176071, U1463205, 91534127, and 21506053), International Cooperation Project 496 of Shanghai Ministry of Science and Technology (14230710700) and Chinese 497 Education Ministry 111 project (B08021).

498 


\section{References}

500 [1] J. Turkevich, G. Kim, Palladium: preparation and catalytic properties of particles of uniform size, Science 169 (1970) 873-879.

502 [2] G.C. Bond, Supported metal catalysts: some unsolved problems, Chem. Soc. Rev. 20 (1991) 441-475.

[3] C.T. Campbell, S.C. Parker, D.E. Starr, The effect of size-dependent nanoparticle energetics on catalyst sintering, Science 298 (2002) 811-814.

[4] S.H. Joo, J.Y. Park, J.R. Renzas, D.R. Butcher, W. Huang, G.A. Somorjai, Size effect of ruthenium nanoparticles in catalytic carbon monoxide oxidation, Nano

[5] R.A. Van Santen, Complementary structure sensitive and insensitive catalytic relationships, Acc. Chem. Res. 42 (2009) 57-66.

[6] W.E. Kaden, T. Wu, W.A. Kunkel, S.L. Anderson, Electronic structure controls reactivity of size-selected $\mathrm{Pd}$ clusters adsorbed on $\mathrm{TiO}_{2}$ surfaces, Science 326 (2009) 826-829.

[7] Y.J. Wang, N.N. Zhao, B.Z. Fang, H. Li, X.T. Bi, H.J. Wang, Carbon-supported Pt-based alloy electrocatalysts for the oxygen reduction reaction in polymer electrolyte membrane fuel cells: particle size, shape, and composition manipulation and their impact to activity, Chem. Rev. 115 (2015) 3433-3467.

[8] G.C. Bond, The effect of the metal to non-metal transition on the activity of gold catalysts, Faraday Discuss. 152 (2011) 277-291.

[9] G. Vilé, D. Albani, M. Nachtegaal, Z.P. Chen, D. Dontsova, M. Antonietti, N. López, J. Pérez-Ramírez, A stable single-site palladium catalyst for hydrogenations, Angew. Chem. Int. Ed. 54 (2015) 11265-11269. 
[10] X.G. Guo, G.Z. Fang, G. Li, H. Ma, H.J. Fan, L. Yu, C. Ma, X. Wu, D.H. Deng, M.M. Wei, D.L. Tan, R. Si, S. Zhang, J.Q. Li, L.T. Sun, Z.C. Tang, X.L. Pan, X.H. Bao, Direct, nonoxidative conversion of methane to ethylene, aromatics, and hydrogen, Science 344 (2014) 616-619.

[11] M. Yang, S. Li, Y. Wang, J.A. Herron, Y. Xu, L.F. Allard, S. Lee, J. Huang, M. Mavrikakis, M. Flytzani-Stephanopoulos, Catalytically active $\mathrm{Au}-\mathrm{O}(\mathrm{OH}) \mathrm{x}$ - species stabilized by alkali ions on zeolites and mesoporous oxides, Science 346 (2014) 1498-1501.

[12] Y.Z. Lu, W. Chen, Sub-nanometre sized metal clusters: from synthetic challenges to the unique property discoveries, Chem. Soc. Rev. 41 (2012) 3594-3623.

[13] Y. Lei, F. Mehmood, S. Lee, J. Greeley, B. Lee, S. Seifert, R.E. Winans, J.W. Elam, R.J. Meyer, P.C. Redfern, D. Teschner, R. Schlögl, M.J. Pellin, L.A. Curtiss, S. Vajda, Increased silver activity for direct propylene epoxidation via subnanometer size effects, Science 328 (2010) 224-228.

[14] M. Valden, X. Lai, D.W. Goodman, Onset of catalytic activity of gold clusters on titania with the appearance of nonmetallic properties, Science 281 (1998) 1647-1650.

[15] O.M. Wilson, M.R. Knecht, J.C. Garcia-Martinez, R.M. Crooks, Effect of Pd nanoparticle size on the catalytic hydrogenation of allyl alcohol, J. Am. Chem. Soc. 128 (2006) 4510-4511.

[16] H. Mistry, R. Reske, Z.H. Zeng, Z.-J. Zhao, J. Greeley, P. Strasser, B.R. Cuenya, Exceptional size-dependent activity enhancement in the electroreduction of $\mathrm{CO}_{2}$ over Au nanoparticles, J. Am. Chem. Soc. 136 (2014) 16473-16476. 
[17] D.F. Gao, H. Zhou, J. Wang, S. Miao, F. Yang, G.X. Wang, J.G. Wang, X.H. Bao, Size-dependent electrocatalytic reduction of $\mathrm{CO}_{2}$ over $\mathrm{Pd}$ nanoparticles, J. Am. Chem. Soc. 137 (2015) 4288-4291.

[18] G. Goor, J. Glenneberg, S. Jacobi, Hydrogen peroxide, in: Ullmann's Encyclopedia of Industrial Chemistry, Wiley-VCH Verlag GmbH \& Co. KGaA, 2007, pp. 393-427.

[19] X. Yu, T. Wu, X.-J. Yang, J. Xu, J. Auzam, R. Semiat, Y.-F. Han, Degradation of trichloroethylene by hydrodechlorination using formic acid as hydrogen source over supported Pd catalysts, J. Hazard. Mater. 305 (2016) 178-189.

[20] X.-J. Yang, P.-F. Tian, H.-L. Wang, J. Xu, Y.-F. Han, Catalytic decomposition of $\mathrm{H}_{2} \mathrm{O}_{2}$ over a $\mathrm{Au} /$ carbon catalyst: a dual intermediate model for the generation of hydroxyl radicals, J. Catal. 336 (2016) 126-132.

[21] X.-J. Yang, X.-M. Xu, J. Xu, Y.-F. Han, Iron oxychloride (FeOCl): an efficient Fenton-like catalyst for producing hydroxyl radicals in degradation of organic contaminants, J. Am. Chem. Soc. 135 (2013) 16058-16061.

[22] X.-J. Yang, X.-M. Xu, X.-C. Xu, J. Xu, H.-L. Wang, R. Semiat, Y.-F. Han, Modeling and kinetics study of bisphenol A (BPA) degradation over an $\mathrm{FeOCl} / \mathrm{SiO}_{2}$ Fenton-like catalyst, Catal. Today 276 (2016) 85-96.

[23] X.-J. Yang, P.-F. Tian, C.X. Zhang, Y.-Q. Deng, J. Xu, J.L. Gong, Y.-F. Han, $\mathrm{Au} /$ carbon as Fenton-like catalysts for the oxidative degradation of bisphenol A, Appl. Catal. B: Environ. 134-135 (2013) 145-152.

[24] X.-J. Yang, P.-F. Tian, X.-M. Zhang, X. Yu, T. Wu, J. Xu, Y.-F. Han, The generation of hydroxyl radicals by hydrogen peroxide decomposition on FeOCl/SBA-15 catalysts for phenol degradation, AIChE J. 61 (2015) 166-176. 
[25] J.K. Edwards, S.J. Freakley, A.F. Carley, C.J. Kiely, G.J. Hutchings, Strategies for designing supported gold-palladium bimetallic catalysts for the direct synthesis of hydrogen peroxide, Acc. Chem. Res. 47 (2014) 845-854.

[26] Y.-F. Han, J.H. Lunsford, Direct formation of $\mathrm{H}_{2} \mathrm{O}_{2}$ from $\mathrm{H}_{2}$ and $\mathrm{O}_{2}$ over a $\mathrm{Pd} / \mathrm{SiO}_{2}$ catalyst: the roles of the acid and the liquid phase, J. Catal. 230 (2005) 313-316.

[27] H.C. Ham, G.S. Hwang, J. Han, S.W. Nam, T.H. Lim, Geometric parameter effects on ensemble contributions to catalysis: $\mathrm{H}_{2} \mathrm{O}_{2}$ formation from $\mathrm{H}_{2}$ and $\mathrm{O}_{2}$ on AuPd alloys. A first principles study, J. Phys. Chem. C 114 (2010) 14922-14928.

[28] H.C. Ham, G.S. Hwang, J. Han, S.W. Nam, T.H. Lim, On the role of Pd ensembles in selective $\mathrm{H}_{2} \mathrm{O}_{2}$ formation on PdAu alloys, J. Phys. Chem. C 113 (2009) $12943-12945$.

[29] T. Deguchi, M. Iwamoto, Catalytic properties of surface sites on Pd clusters for direct $\mathrm{H}_{2} \mathrm{O}_{2}$ synthesis from $\mathrm{H}_{2}$ and $\mathrm{O}_{2}$ : a DFT study, J. Phys. Chem. C 117 (2013) $18540-18548$.

[30] A.V. Beletskaya, D.A. Pichugina, A.F. Shestakov, N.E. Kuzmenko, Formation of $\mathrm{H}_{2} \mathrm{O}_{2}$ on $\mathrm{Au}_{20}$ and $\mathrm{Au}_{19} \mathrm{Pd}$ clusters: understanding the structure effect on the atomic level, J. Phys. Chem. A 117 (2013) 6817-6826.

[31] B.C.H. Steele, A. Heinzel, Materials for fuel-cell technologies, Nature 414 (2001) 345-352.

[32] D.C. Ford, A.U. Nilekar, Y. Xu, M. Mavrikakis, Partial and complete reduction of $\mathrm{O}_{2}$ by hydrogen on transition metal surfaces, Surf. Sci. 604 (2010) 1565-1575.

[33] L.K. Ouyang, P.-F. Tian, G.-J. Da, X.-C. Xu, C. Ao, T.-Y. Chen, R. Si, J. Xu, Y.-F. Han, The origin of active sites for direct synthesis of $\mathrm{H}_{2} \mathrm{O}_{2}$ on $\mathrm{Pd} / \mathrm{TiO}_{2}$ catalysts: interfaces of Pd and PdO domains, J. Catal. 321 (2015) 70-80. 
[34] L.K. Ouyang, G.-J. Da, P.-F. Tian, T.-Y. Chen, G.-D. Liang, J. Xu, Y.-F. Han, Insight into active sites of $\mathrm{Pd}-\mathrm{Au} / \mathrm{TiO}_{2}$ catalysts in hydrogen peroxide synthesis directly from $\mathrm{H}_{2}$ and $\mathrm{O}_{2}$, J. Catal. 311 (2014) 129-136.

[35] L.C. Grabow, B. Hvolbæk, H. Falsig, J.K. Nørskov, Search directions for direct $\mathrm{H}_{2} \mathrm{O}_{2}$ synthesis catalysts starting from $\mathrm{Au}_{12}$ nanoclusters, Top. Catal. 55 (2012) 336-344.

[36] A. Staykov, T. Kamachi, T. Ishihara, K. Yoshizawa, Theoretical study of the direct synthesis of $\mathrm{H}_{2} \mathrm{O}_{2}$ on $\mathrm{Pd}$ and $\mathrm{Pd} / \mathrm{Au}$ surfaces, J. Phys. Chem. C 112 (2008) 19501-19505.

[37] J.K. Edwards, E. Ntainjua, A.F. Carley, A.A. Herzing, C.J. Kiely, G.J. Hutchings, Direct synthesis of $\mathrm{H}_{2} \mathrm{O}_{2}$ from $\mathrm{H}_{2}$ and $\mathrm{O}_{2}$ over gold, palladium, and gold-palladium catalysts supported on acid-pretreated $\mathrm{TiO}_{2}$, Angew. Chem. Int. Ed. 48 (2009) 8512-8515.

[38] J.K. Edwards, J. Pritchard, L. Lu, M. Piccinini, G. Shaw, A.F. Carley, D.J. Morgan, C.J. Kiely, G.J. Hutchings, The direct synthesis of hydrogen peroxide using platinum-promoted gold-palladium catalysts, Angew. Chem. Int. Ed. 53 (2014) 2381-2384.

[39] J.K. Edwards, B. Solsona, E.N. Ntainjua, A.F. Carley, A.A. Herzing, C.J. Kiely, G.J. Hutchings, Switching off hydrogen peroxide hydrogenation in the direct synthesis process, Science 323 (2009) 1037-1041.

[40] S.J. Freakley, Q. He, J.H. Harrhy, L. Lu, D.A. Crole, D.J. Morgan, E.N. Ntainjua, J.K. Edwards, A.F. Carley, A.Y. Borisevich, C.J. Kiely, G.J. Hutchings, Palladium-tin catalysts for the direct synthesis of $\mathrm{H}_{2} \mathrm{O}_{2}$ with high selectivity, Science 351 (2016) 965-968. 
618 [41] M.I. Kay, R.A. Young, A.S. Posner, Crystal structure of hydroxyapatite, Nature $619204(1964) 1050-1052$

620 [42] B. Ravel, M. Newville, ATHENA, ARTEMIS, HEPHAESTUS: data analysis for 621 X-ray absorption spectroscopy using IFEFFIT, J. Synchrotron Radiat. 12 (2005) $622 \quad 537-541$.

623 [43] M. Newville, IFEFFIT: interactive XAFS analysis and FEFF fitting, J. $624 \quad$ Synchrotron Radiat. 8 (2001) 322-324.

625 [44] G. Kresse, J. Furthmüller, Efficiency of ab-initio total energy calculations for 626 metals and semiconductors using a plane-wave basis set, Comp. Mater. Sci. 6 $627 \quad$ (1996) $15-50$.

628 [45] G. Kresse, J. Furthmüller, Efficient iterative schemes for total-energy calculations 629 using a plane-wave basis set, Phys. Rev. B 54 (1996) 11169-11186.

630 [46] G. Kresse, D. Joubert, From ultrasoft pseudopotentials to the projector $631 \quad$ augmented-wave method, Phys. Rev. B 59 (1999) 1758-1775.

632 [47] P.E. Blöchl, Projector augmented-wave method, Phys. Rev. B 50 (1994) 633 17953-17979.

634 [48] J.P. Perdew, K. Burke, M. Ernzerhof, Generalized gradient approximation made 635 simple, Phys. Rev. Lett. 77 (1996) 3865-3868.

636 [49] J.P. Perdew, W. Yue, Accurate and simple density functional for the electronic 637 exchange energy: generalized gradient approximation, Phys. Rev. B 33 (1986) $638 \quad 8800-8802$.

639 [50] M. Methfessel, A.T. Paxton, High-precision sampling for brillouin-zone $640 \quad$ integration in metals, Phys. Rev. B 40 (1989) 3616-3621. 
641 [51] A. Plauck, E.E. Stangland, J.A. Dumesic, M. Mavrikakis, Active sites and 642 mechanisms for $\mathrm{H}_{2} \mathrm{O}_{2}$ decomposition over Pd catalysts, Proc. Natl. Acad. Sci. USA $643 \quad 113(2016)$ E1973-E1982.

644 [52] R. Todorovic, R.J. Meyer, A comparative density functional theory study of the 645 direct synthesis of $\mathrm{H}_{2} \mathrm{O}_{2}$ on $\mathrm{Pd}$, Pt and $\mathrm{Au}$ surfaces, Catal. Today 160 (2011) 242-248.

647 [53] G. Henkelman, B.P. Uberuaga, H. Jonsson, A climbing image nudged elastic band 648 method for finding saddle points and minimum energy paths, J. Chem. Phys. 113 $649 \quad$ (2000) 9901-9904.

650 [54] A.A. Gokhale, S. Kandoi, J.P. Greeley, M. Mavrikakis, J.A. Dumesic, 651 Molecular-level descriptions of surface chemistry in kinetic models using density 652 functional theory, Chem. Eng. Sci. 59 (2004) 4679-4691.

653 [55] R.D. Cortright, J.A. Dumesic, Kinetics of heterogeneous catalytic reactions: 654 analysis of reaction schemes, Adv. Catal. 46 (2001), 161-264.

655 [56] K. Yamaguchi, K. Mori, T. Mizugaki, K. Ebitani, K. Kaneda, Creation of a 656 monomeric $\mathrm{Ru}$ species on the surface of hydroxyapatite as an efficient 657 heterogeneous catalyst for aerobic alcohol oxidation, J. Am. Chem. Soc. 122 (2000) $658 \quad 7144-7145$.

659 [57] F. Gao, Y. Wang, D.W. Goodman, CO oxidation over AuPd(100) from ultrahigh 660 vacuum to near-atmospheric pressures: the critical role of contiguous Pd atoms, J. $661 \quad$ Am. Chem. Soc. 131 (2009) 5734-5735.

662 [58] F. Gao, Y. Wang, D.W. Goodman, CO oxidation over AuPd(100) from ultrahigh 663 vacuum to near-atmospheric pressures: $\mathrm{CO}$ adsorption-induced surface segregation 664 and reaction kinetics, J. Phys. Chem. C 113 (2009) 14993-15000. 
[59] J. Xu, L.K. Ouyang, W. Mao, X.-J. Yang, X.-C. Xu, J.-J. Su, T.-Z. Zhuang, H. Li, Y.-F. Han, Operando and kinetic study of low-temperature, lean-burn methane combustion over a $\mathrm{Pd} / \gamma-\mathrm{Al}_{2} \mathrm{O}_{3}$ catalyst, ACS Catal. 2 (2012) 261-269.

[60] G. Zheng, E.I. Altman, The oxidation of Pd(111), Surf. Sci., 462 (2000) 151-168.

[61] H. Conrad, G. Ertl, J. Küppers, E.E. Latta, Interaction of $\mathrm{NO}$ and $\mathrm{O}_{2}$ with $\mathrm{Pd}(111)$ surfaces. II, Surf. Sci. 65 (1977) 245-260.

[62] J.A. Hinojosa, H.H. Kan, J.F. Weaver, Molecular chemisorption of $\mathrm{O}_{2}$ on a PdO(101) thin film on Pd(111), J. Phys. Chem. C 112 (2008) 8324-8331.

[63] S. Penner, P. Bera, S. Pedersen, L.T. Ngo, J.J.W. Harris, C.T. Campbell, Interactions of $\mathrm{O}_{2}$ with $\mathrm{Pd}$ nanoparticles on $\alpha-\mathrm{Al}_{2} \mathrm{O}_{3}(0001)$ at low and high $\mathrm{O}_{2}$ pressures, J. Phys. Chem. B 110 (2006) 24577-24584.

[64] X. Guo, A. Hoffman, J.T. Yates, Adsorption kinetics and isotopic equilibration of oxygen adsorbed on the Pd(111) surface, J. Chem. Phys. 90 (1989) 5787-5792.

[65] K.W. Kolasinski, F. Cemic, E. Hasselbrink, $\mathrm{O}_{2} / \mathrm{Pd}(111)$. Clarification of the correspondence between thermal desorption features and chemisorption states, Chem. Phys. Lett. 219 (1994) 113-117.

[66] S. Penner, D. Wang, B. Jenewein, H. Gabasch, B. Klötzer, A. Knop-Gericke, R. Schlögl, K. Hayek, Growth and decomposition of aligned and ordered PdO nanoparticles, J. Chem. Phys. 125 (2006) 094703.

[67] N.M. Wilson, D.W. Flaherty, Mechanism for the direct synthesis of $\mathrm{H}_{2} \mathrm{O}_{2}$ on $\mathrm{Pd}$ clusters: heterolytic reaction pathways at the liquid-solid interface, J. Am. Chem. Soc. 138 (2016) 574-586.

[68] J.H. Lunsford, The direct formation of $\mathrm{H}_{2} \mathrm{O}_{2}$ from $\mathrm{H}_{2}$ and $\mathrm{O}_{2}$ over palladium catalysts, J. Catal. 216 (2003) 455-460. 
689 [69] Q.S. Liu, J.H. Lunsford, The roles of chloride ions in the direct formation of $\mathrm{H}_{2} \mathrm{O}_{2}$

690 from $\mathrm{H}_{2}$ and $\mathrm{O}_{2}$ over a $\mathrm{Pd} / \mathrm{SiO}_{2}$ catalyst in a $\mathrm{H}_{2} \mathrm{SO}_{4} /$ ethanol system, J. Catal. 239 $691 \quad$ (2006) 237-243.

692 [70] R. Imbihl, J.E. Demuth, Adsorption of oxygen on a $\operatorname{Pd}(111)$ surface studied by 693 high resolution electron energy loss spectroscopy (EELS), Surf. Sci. 173 (1986) $694 \quad 395-410$.

695 [71] T. Chen, E. Kertalli, T.A. Nijhuis, S.G. Podkolzin, Effects of hydrogen and 696 propylene presence on decomposition of hydrogen peroxide over palladium 697 catalysts, J. Catal. 341 (2016) 72-81.

698 [72] S. Schauermann, H.-J. Freund, Model approach in heterogeneous catalysis: 699 kinetics and thermodynamics of surface reactions, Acc. Chem. Res. 48 (2015) 700 $2775-2782$.

701

702 


\section{Captions}

705

706

707

708

709

710

711

712

713

714

715

716

717

718

719

720

721

722

Fig. 1. Time-dependent $\mathrm{H}_{2} \mathrm{O}_{2}$ synthesis over different $\mathrm{Pd} / \mathrm{HAp}$ catalysts. (A) $\mathrm{H}_{2}$ conversion. (B) $\mathrm{H}_{2} \mathrm{O}_{2}$ concentration. (C) $\mathrm{H}_{2} \mathrm{O}_{2}$ selectivity.

Fig. 2. XRD patterns of $\mathrm{Pd} / \mathrm{HAp}$ catalysts. (A and B) XRD patterns of HAp and Pd/HAp catalysts with different Pd loadings. (C and D) XRD patterns of HAp (a) and 3.0 wt \% Pd/HAp catalysts (b to f) under different calcination-reduction temperatures ((a) $673 \mathrm{~K}-573 \mathrm{~K}$, (b) 473K-473 K, (c) $573 \mathrm{~K}-573 \mathrm{~K}$, (d) $673 \mathrm{~K}-573 \mathrm{~K}$, (e) 773 K-573 K, (f) $873 \mathrm{~K}-573 \mathrm{~K}$ ).

Fig. 3. Morphology of Pd/HAp catalysts. (A to E) BF-TEM images and the size distribution of the Pd catalysts with the loadings of $0.5 \mathrm{wt} \%, 1.0 \mathrm{wt} \%, 2.0 \mathrm{wt} \%, 3.0$ wt $\%$, and 5.0 wt $\%$, respectively. ( $F$ and $\mathrm{G}$ ) ADF-TEM images and the size distribution of the Pd catalysts with the loadings of $0.5 \mathrm{wt} \%, 1.0 \mathrm{wt} \%$, respectively. (H) Aberration-corrected STEM image of the $1.0 \mathrm{wt} \%$ catalyst.

Fig. 4. $\mathrm{k}^{2}$-Weighted Fourier transform Pd K-edge EXAFS spectra of the fresh catalysts ((a) Pure PdO, (b) Pd(I.E.), (c) 0.5 wt \% Pd, (d) 1.0 wt \% Pd, (e) 2.0 wt \% Pd, (f) 3.0 wt \% Pd, (g) 5.0 wt \% Pd, (h) Pd foil). 
723

724

725

726

727

728

729

730

731

732

733

734

735

736

737

738

739

740

741

742

Fig. 5. In situ DRIFTS of CO adsorption over different catalysts at $283 \mathrm{~K}$ in an Ar

flow (50 mL/min) ((a) HAp, (b) 0.5 wt \% Pd, (c) 1.0 wt \% Pd, (d) 2.0 wt \% Pd, (e) 3.0 wt $\% \mathrm{Pd}$, (f) $5.0 \mathrm{wt} \% \mathrm{Pd}$ ).

Fig. 6. Pd3d XPS spectra of the fresh catalysts ((a) 0.5 wt \% Pd, (b) 1.0 wt \% Pd, (c) 2.0 wt $\% \mathrm{Pd}$, (d) 3.0 wt \% Pd, (e) 5.0 wt \% Pd).

Fig. 7. $\mathrm{O}_{2}-\mathrm{TPD}$ profiles obtained for different catalysts in an Ar flow $(50 \mathrm{~mL} / \mathrm{min})$

with a ramping rate of $20 \mathrm{~K} / \mathrm{min}$ ((a) HAp, (b) $0.5 \mathrm{wt} \% \mathrm{Pd}$, (c) $1.0 \mathrm{wt} \% \mathrm{Pd}$, (d) 2.0 wt $\% \mathrm{Pd}$, (e) 3.0 wt $\% \mathrm{Pd}$, (f) 5.0 wt \% Pd).

Fig. 8. Models and results of DFT calculations. (A to D) $\mathrm{Pd}_{1} / \mathrm{HAp}, \mathrm{Pd}_{3} / \mathrm{HAp}$, $\mathrm{Pd}_{10} / \mathrm{HAp}$, and $\mathrm{Pd}(111)$ models used for simulating mono-dispersed single Pd sites, two dimensional subnano Pd clusters, three dimensional subnano Pd clusters, and Pd nanoparticles with crystalline phase, respectively. Blue, red, white, purple, and green spheres are palladium, oxygen, hydrogen, phosphorus, and calcium atoms, respectively. (E) Calculating ratios of rate constants of the formation of $\mathrm{OOH}$ to the dissociation of $\mathrm{O}_{2}\left(\mathrm{R}_{\mathrm{A}}\right)$ and those of equilibrium constants $\left(\mathrm{R}_{\mathrm{B}}\right)$ over $\mathrm{Pd}_{3} / \mathrm{HAp}$, $\mathrm{Pd}_{10} / \mathrm{HAp}$, and $\mathrm{Pd}(111)$. 
743 Fig. 9. Relations between the catalytic performance for $\mathrm{H}_{2} \mathrm{O}_{2}$ synthesis, the $\mathrm{Pd}$ 744 particle sizes, and the structures of active sites. (A) Size dependence of $\mathrm{H}_{2} \mathrm{O}_{2}$ 745 selectivity over Pd/HAp catalysts ((a)-(e): Catalysts calcined at $673 \mathrm{~K}$ with the $\mathrm{Pd}$ 746 loadings of $0.5 \mathrm{wt} \%, 1.0 \mathrm{wt} \%, 2.0 \mathrm{wt} \%, 3.0 \mathrm{wt} \%$, and $5.0 \mathrm{wt} \%$, respectively; (f) $7473.0 \mathrm{wt} \% \mathrm{Pd}$ calcined at $773 \mathrm{~K}$ (Fig. S2A and Table S1); (g) $3.0 \mathrm{wt} \% \mathrm{Pd}$ calcined at $748 \quad 873 \mathrm{~K}$ (Fig. S2B and Table S1)). (B) Structures of catalysts corresponding to three 749 scales of particle sizes and proposed mechanism for $\mathrm{H}_{2} \mathrm{O}_{2}$ synthesis. Blue, red, white, 750 purple, and green spheres are palladium, oxygen, hydrogen, phosphorus, and calcium 751 atoms, respectively. 
753 Performance of Pd/HAp catalysts with different Pd loadings ${ }^{a}$.

\begin{tabular}{|c|c|c|c|c|}
\hline Catalyst & $\begin{array}{c}\mathbf{H}_{2} \\
\text { Conversion (\%) } \\
\end{array}$ & $\begin{array}{c}\mathrm{H}_{2} \mathrm{O}_{2} \\
\text { Selectivity }(\%)\end{array}$ & $\begin{array}{c}\mathrm{H}_{2} \mathrm{O}_{2} \text { Productivity } \\
\left(\mathrm{mmol} \mathrm{H}_{2} \mathrm{O}_{2} \mathrm{~g}_{\mathrm{Pd}}{ }^{-1} \cdot \mathbf{h}^{-1}\right)\end{array}$ & $\begin{array}{l}\text { TOF } \\
\left(h^{-1}\right)\end{array}$ \\
\hline $5.0 \mathrm{wt} \% \mathrm{Pd}$ & 17.8 & 43 & 741 & 191 \\
\hline $3.0 \mathrm{wt} \% \mathrm{Pd}$ & 15.5 & 45 & 1126 & 269 \\
\hline $2.0 \mathrm{wt} \% \mathrm{Pd}$ & 11.1 & 51 & 1378 & 290 \\
\hline $1.0 \mathrm{wt} \% \mathrm{Pd}$ & 5.8 & 67 & 1873 & 340 \\
\hline 0.5 wt $\% \mathrm{Pd}$ & 2.1 & 94 & 1857 & 284 \\
\hline Pd(I.E.) & n.d. & n.d. & n.d. & n.d. \\
\hline
\end{tabular}

754 a Reaction conditions: $60 \mathrm{~mL}$ solvent (ethanol with $0.38 \mathrm{~mL} \mathrm{H}_{2} \mathrm{SO}_{4}$ ), total gas flow 755 rate of $60 \mathrm{~mL} / \mathrm{min}\left(\mathrm{H}_{2}: \mathrm{O}_{2}: \mathrm{N}_{2}=9: 36: 15\right)$, atmospheric pressure, $50 \mathrm{mg}$ catalyst, $283 \mathrm{~K}$,

7561000 rpm, 0.5 h. Pd(I.E.), Pd catalyst prepared using ion-exchanging method. n.d., not 757 determined. 
Table 2

759 Numerical results (CNs CN, Distances R, Debye-Waller Factors $\sigma^{2}$ ) for Pd-O and $760 \mathrm{Pd}-\mathrm{Pd}$ bonds in $\mathrm{Pd} / \mathrm{HAp}$.

\begin{tabular}{|c|c|c|c|c|c|c|}
\hline \multirow{2}{*}{ Sample } & \multicolumn{2}{|c|}{$\mathrm{Pd}-\mathrm{O}$} & \multicolumn{2}{|c|}{ Pd-Pd } & \multirow{2}{*}{$\sigma^{2}$} & \multirow{2}{*}{$\Delta \mathrm{E}_{0}(\mathrm{eV})$} \\
\hline & $\mathrm{R}(\AA)$ & $\mathrm{CN}$ & $\mathrm{R}(\AA)$ & $\mathrm{CN}$ & & \\
\hline $\mathrm{PdO}$ & 2.00 & 8 & - & - & - & - \\
\hline Pd (IE) & $2.01 \pm 0.03$ & $3.1 \pm 1.6$ & - & - & $0.000 \pm 0.005$ & - \\
\hline $0.5 \% \mathrm{Pd}$ & $2.11 \pm 0.03$ & $3.3 \pm 0.8$ & $2.80 \pm 0.03$ & $1.1 \pm 0.6$ & $0.001 \pm 0.004$ & - \\
\hline $1.0 \% \mathrm{Pd}$ & $2.16 \pm 0.02$ & $4.8 \pm 2.0$ & $2.74 \pm 0.04$ & $6.0 \pm 0.8$ & $0.007 \pm 0.001$ & $-0.5 \pm 0.8$ \\
\hline $2.0 \% \mathrm{Pd}$ & $\begin{array}{l}2.06 \pm 0.02 \\
2.58 \pm 0.03\end{array}$ & $\begin{array}{l}2.2 \pm 0.7 \\
3.2 \pm 1.0\end{array}$ & $2.73 \pm 0.01$ & $7.7 \pm 1.1$ & $0.007 \pm 0.001$ & $-2.3 \pm 1.0$ \\
\hline $3.0 \% \mathrm{Pd}$ & $\begin{array}{l}2.05 \pm 0.03 \\
2.56 \pm 0.03\end{array}$ & $\begin{array}{l}2.1 \pm 0.7 \\
3.5 \pm 1.0\end{array}$ & $2.73 \pm 0.01$ & $7.9 \pm 1.1$ & $0.007 \pm 0.001$ & $-2.2 \pm 0.9$ \\
\hline $5.0 \% \mathrm{Pd}$ & $\begin{array}{l}2.06 \pm 0.04 \\
2.58 \pm 0.04\end{array}$ & $\begin{array}{l}1.6 \pm 0.8 \\
2.5 \pm 1.0\end{array}$ & $2.73 \pm 0.01$ & $8.3 \pm 1.1$ & $0.006 \pm 0.001$ & $-1.5 \pm 0.9$ \\
\hline Pd foil & - & - & 2.73 & 12 & - & - \\
\hline
\end{tabular}

761 
763
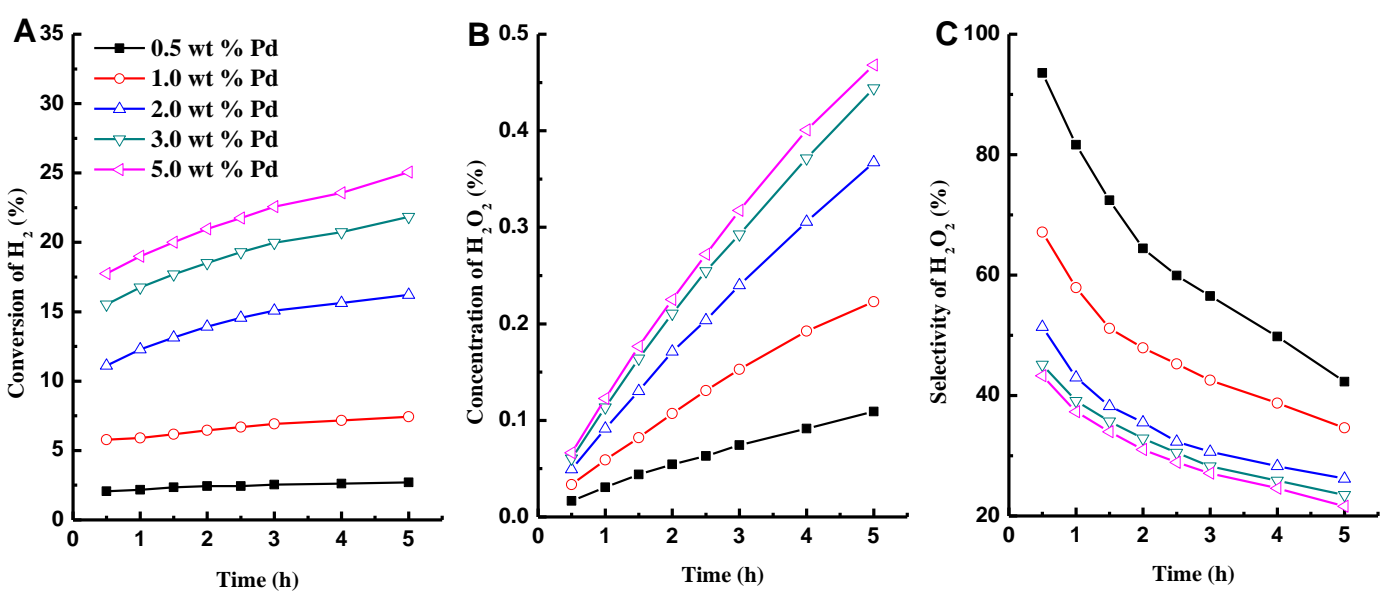

765 Fig. 1. Time-dependent $\mathrm{H}_{2} \mathrm{O}_{2}$ synthesis over different $\mathrm{Pd} / \mathrm{HAp}$ catalysts. (A) $\mathrm{H}_{2}$

766 conversion. (B) $\mathrm{H}_{2} \mathrm{O}_{2}$ concentration. (C) $\mathrm{H}_{2} \mathrm{O}_{2}$ selectivity. 

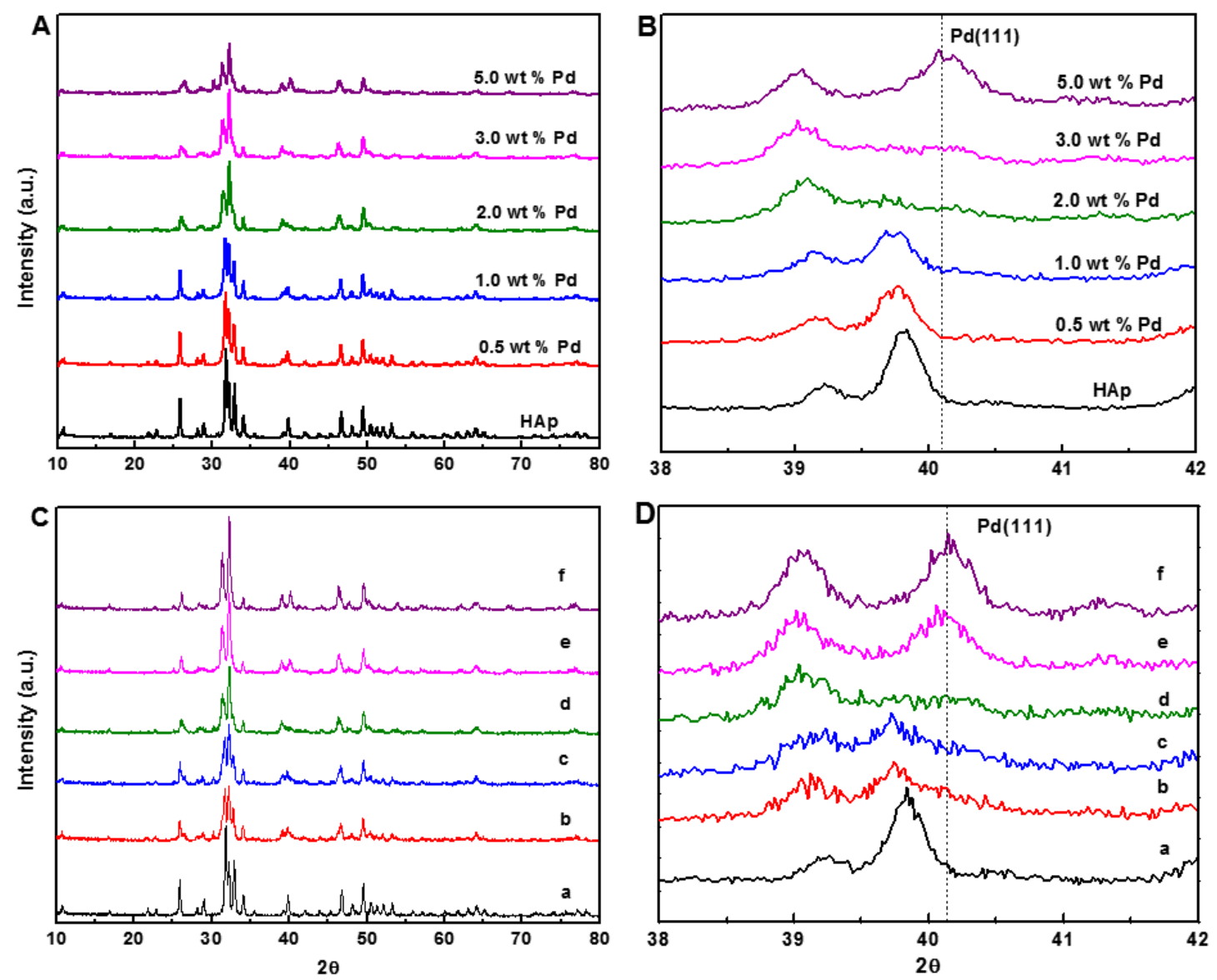

Fig. 2. XRD patterns of $\mathrm{Pd} / \mathrm{HAp}$ catalysts. (A and $\mathrm{B}$ ) XRD patterns of HAp and

Pd/HAp catalysts with different Pd loadings. (C and D) XRD patterns of HAp (a) and

$3.0 \mathrm{wt} \% \mathrm{Pd} / \mathrm{HAp}$ catalysts (b to f) under different calcination-reduction temperatures

((a) $673 \mathrm{~K}-573 \mathrm{~K}$, (b) 473K-473 K, (c) $573 \mathrm{~K}-573 \mathrm{~K}$, (d) $673 \mathrm{~K}-573 \mathrm{~K}$, (e) 773 K-573

K, (f) $873 \mathrm{~K}-573 \mathrm{~K}$ ). 

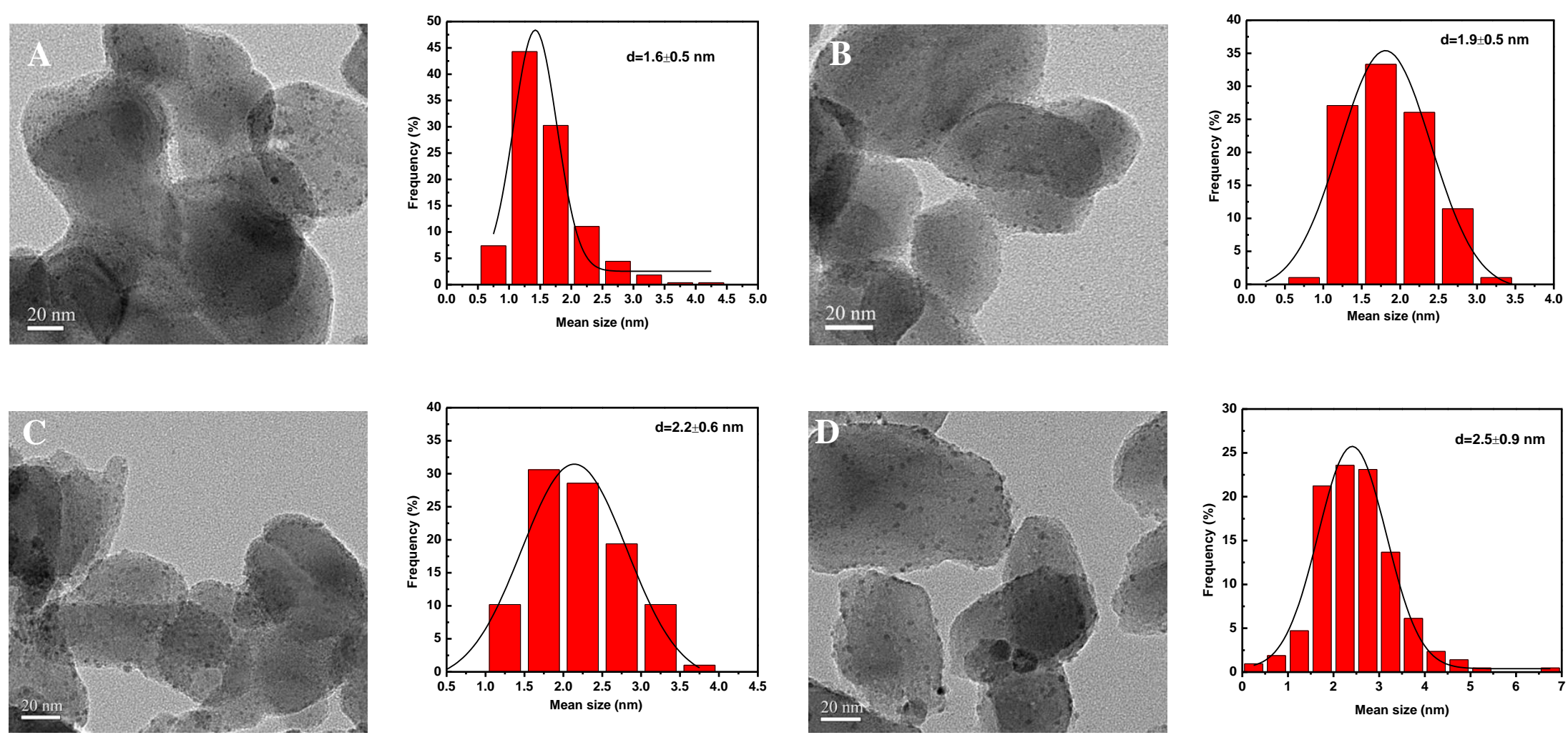

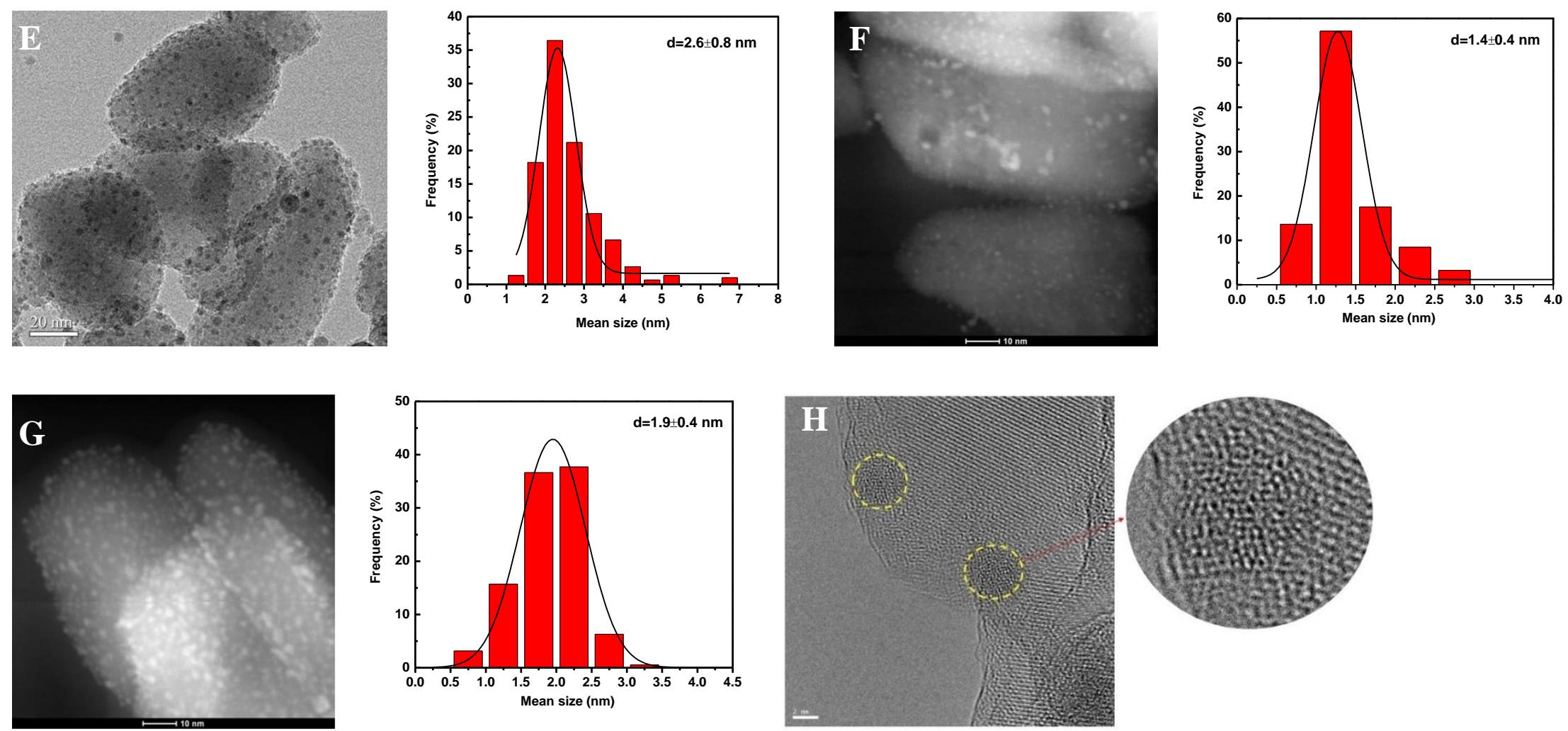

Fig. 3. Morphology of Pd/HAp catalysts. (A to E) BF-TEM images and the size distribution of the Pd catalysts with the loadings of 0.5 wt $\%, 1.0$ wt $\%, 2.0 \mathrm{wt} \%, 3.0 \mathrm{wt} \%$, and $5.0 \mathrm{wt} \%$, respectively. (F and G) ADF-TEM images and the size distribution of the Pd catalysts with the loadings of $0.5 \mathrm{wt} \%, 1.0 \mathrm{wt} \%$, respectively. (H) Aberration-corrected STEM image of the $1.0 \mathrm{wt} \%$ catalyst. 


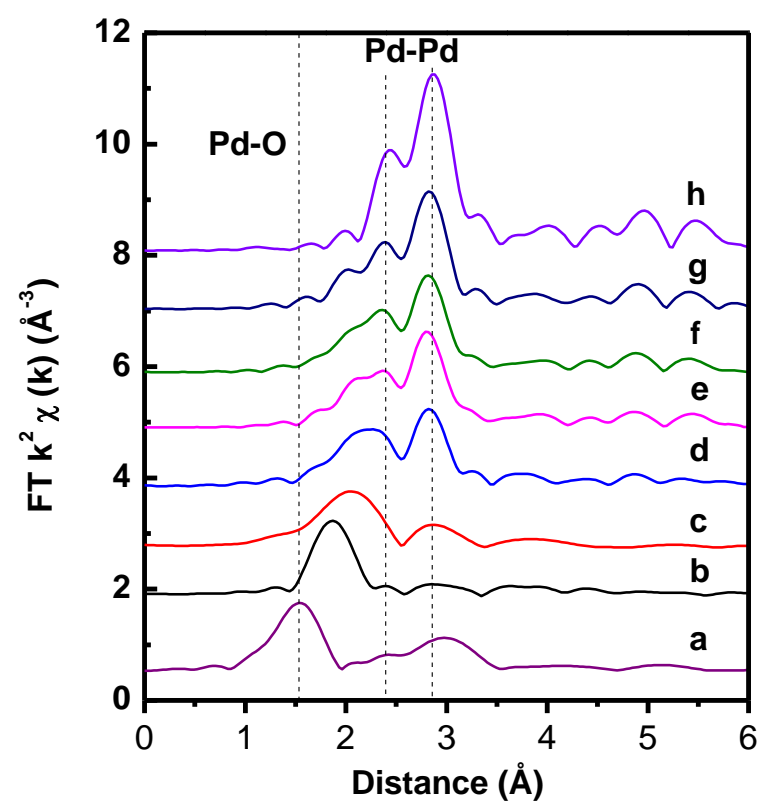

781

782 Fig. 4. $\mathrm{k}^{2}$-Weighted Fourier transform Pd K-edge EXAFS spectra of the fresh

783 catalysts ((a) Pure PdO, (b) Pd(I.E.), (c) 0.5 wt \% Pd, (d) 1.0 wt \% Pd, (e) 2.0 wt \%

$784 \mathrm{Pd},(\mathrm{f}) 3.0$ wt \% Pd, (g) 5.0 wt \% Pd, (h) Pd foil). 


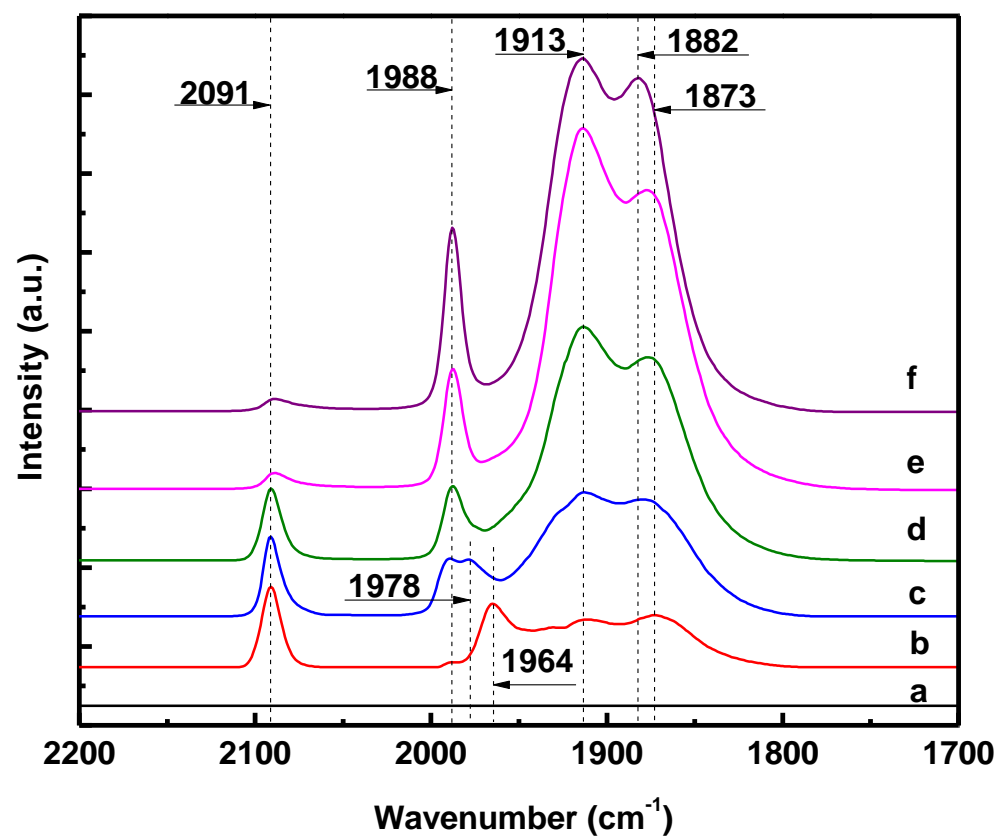

785

786 Fig. 5. In situ DRIFTS of CO adsorption over different catalysts at $283 \mathrm{~K}$ in an $\mathrm{Ar}$

787 flow (50 mL/min) ((a) HAp, (b) $0.5 \mathrm{wt} \% \mathrm{Pd}$, (c) $1.0 \mathrm{wt} \% \mathrm{Pd}$, (d) $2.0 \mathrm{wt} \% \mathrm{Pd}$, (e) 3.0

788 wt $\% \mathrm{Pd}$, (f) 5.0 wt \% Pd). 


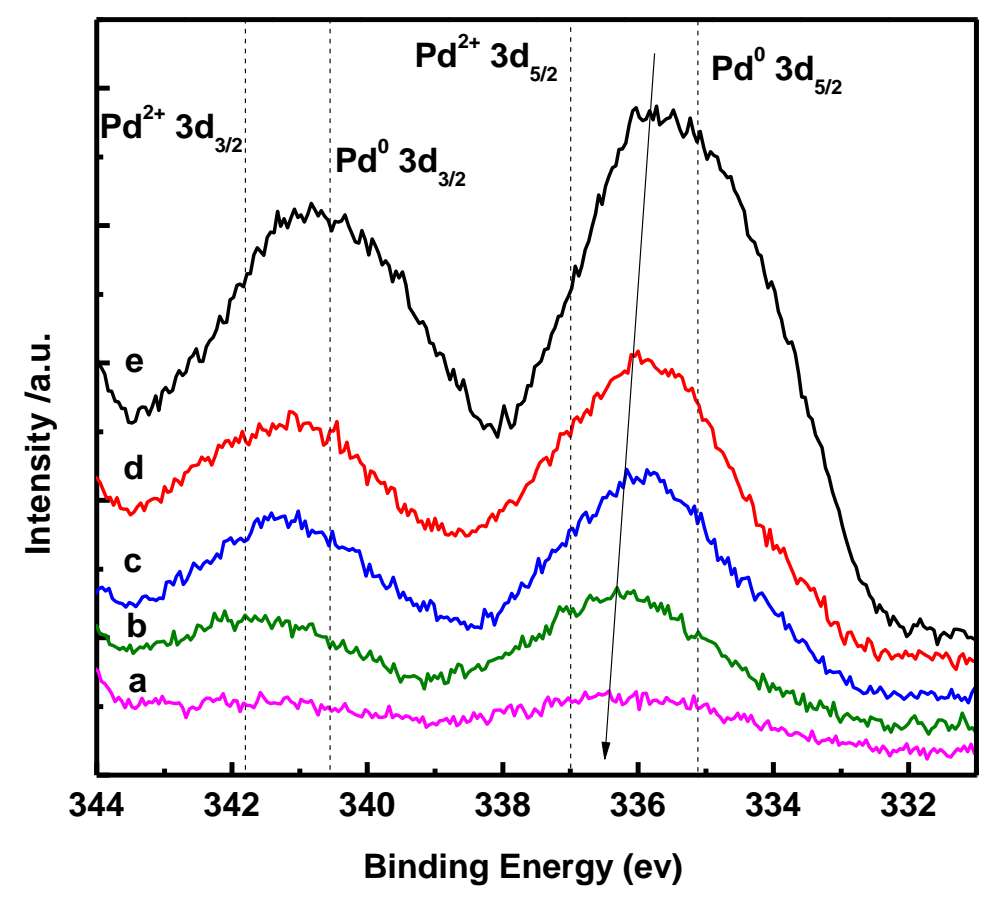

789

790 Fig. 6. Pd3d XPS spectra of the fresh catalysts ((a) $0.5 \mathrm{wt} \% \mathrm{Pd}$, (b) $1.0 \mathrm{wt} \% \mathrm{Pd}$, (c)

$7912.0 \mathrm{wt} \% \mathrm{Pd}$, (d) $3.0 \mathrm{wt} \% \mathrm{Pd}$, (e) $5.0 \mathrm{wt} \% \mathrm{Pd}$ ). 


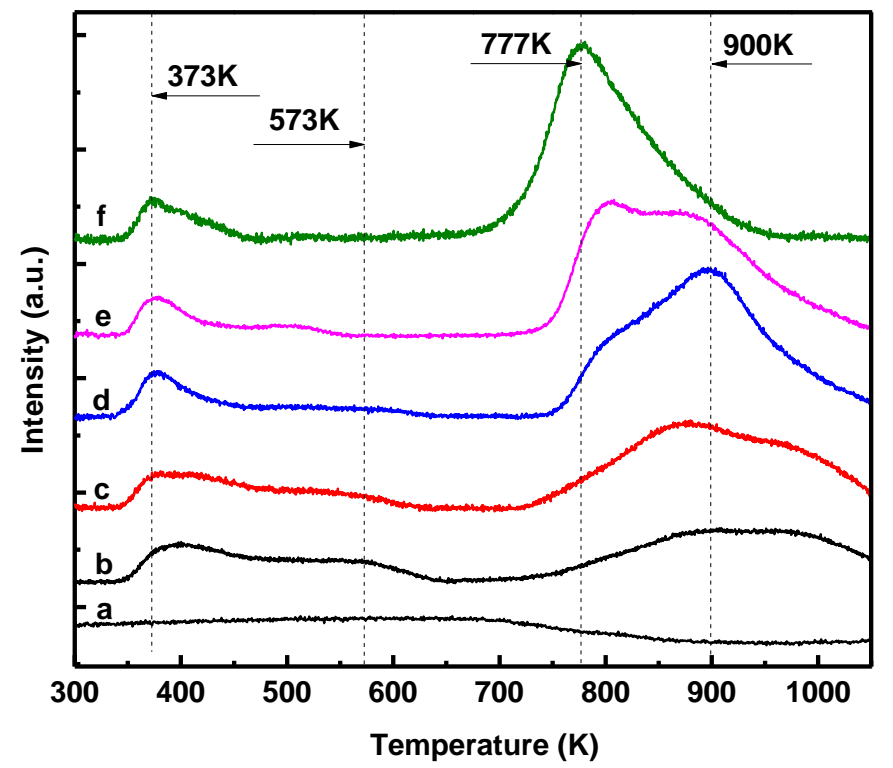

792

793 Fig. 7. $\mathrm{O}_{2}$-TPD profiles obtained for different catalysts in an Ar flow (50 mL/min)

794 with a ramping rate of $20 \mathrm{~K} / \mathrm{min}$ ((a) HAp, (b) 0.5 wt \% Pd, (c) 1.0 wt \% Pd, (d) 2.0 795 wt \% Pd, (e) 3.0 wt \% Pd, (f) 5.0 wt \% Pd). 
A $\quad$ B
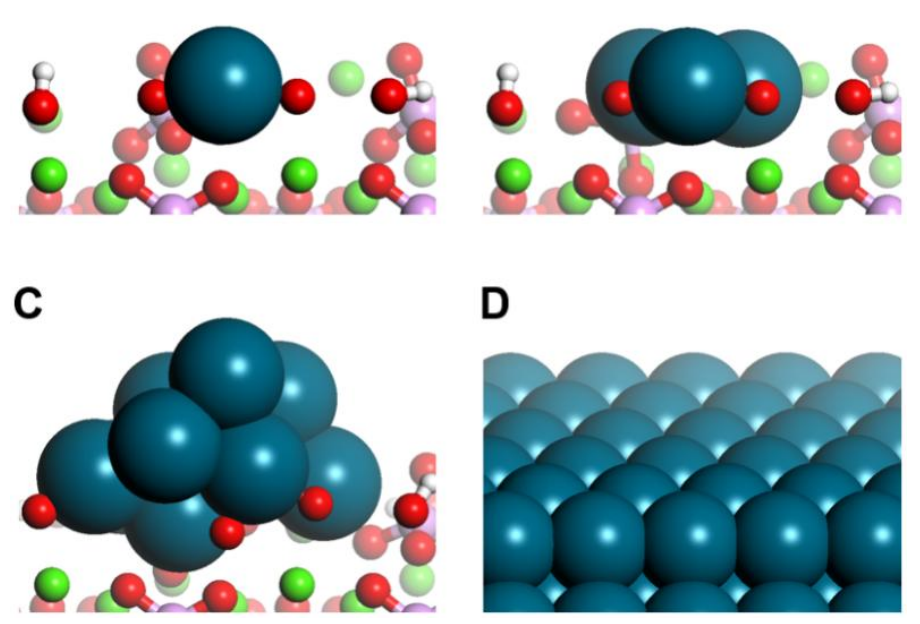

D
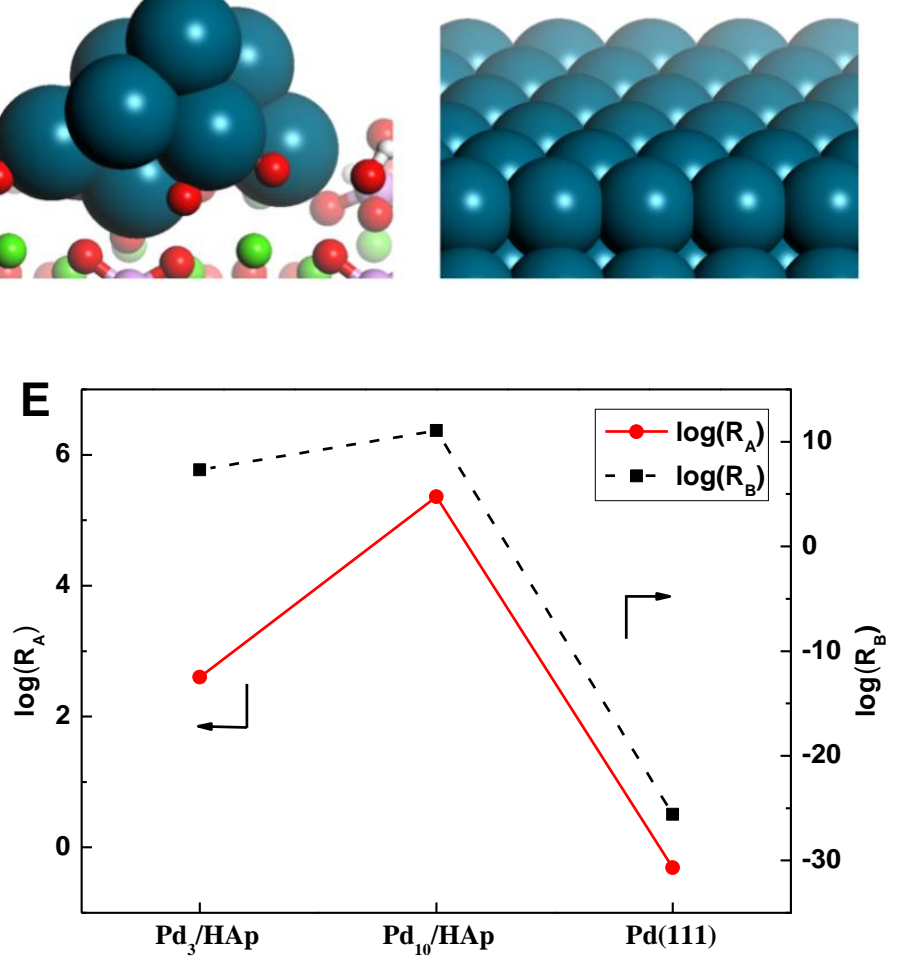

797

798 Fig. 8. Models and results of DFT calculations. (A to D) $\mathrm{Pd}_{1} / \mathrm{HAp}, \mathrm{Pd}_{3} / \mathrm{HAp}$,

$799 \mathrm{Pd}_{10} / \mathrm{HAp}$, and $\mathrm{Pd}(111)$ models used for simulating mono-dispersed single Pd sites,

800 two dimensional subnano Pd clusters, three dimensional subnano Pd clusters, and Pd

801 nanoparticles with crystalline phase, respectively. Blue, red, white, purple, and green

802 spheres are palladium, oxygen, hydrogen, phosphorus, and calcium atoms,

803 respectively. (E) Calculating ratios of rate constants of the formation of $\mathrm{OOH}$ to the

804 dissociation of $\mathrm{O}_{2}\left(\mathrm{R}_{\mathrm{A}}\right)$ and those of equilibrium constants $\left(\mathrm{R}_{\mathrm{B}}\right)$ over $\mathrm{Pd}_{3} / \mathrm{HAp}$,

$805 \mathrm{Pd}_{10} / \mathrm{HAp}$, and $\mathrm{Pd}(111)$. 
A

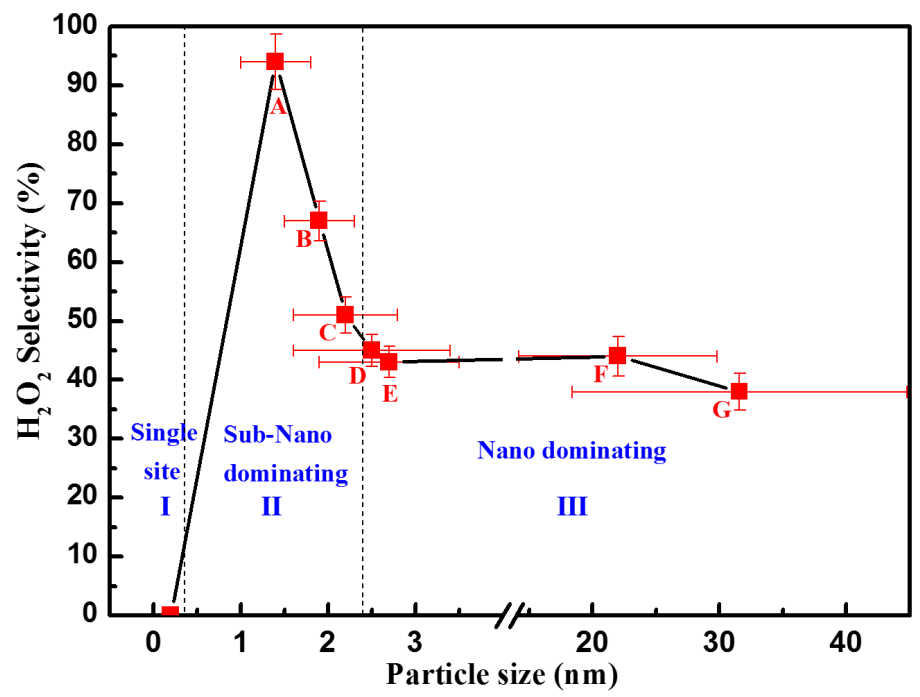

806

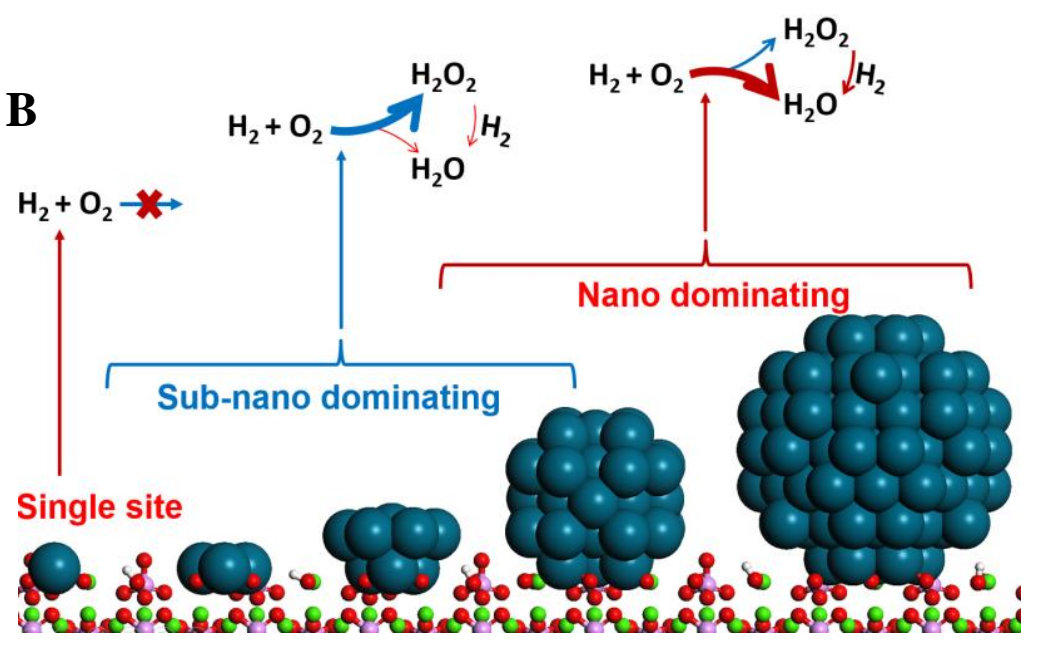

Fig. 9. Relations between the catalytic performance for $\mathrm{H}_{2} \mathrm{O}_{2}$ synthesis, the $\mathrm{Pd}$ particle sizes, and the structures of active sites. (A) Size dependence of $\mathrm{H}_{2} \mathrm{O}_{2}$ selectivity over Pd/HAp catalysts ((a)-(e): Catalysts calcined at $673 \mathrm{~K}$ with the $\mathrm{Pd}$

811 loadings of $0.5 \mathrm{wt} \%, 1.0 \mathrm{wt} \%, 2.0 \mathrm{wt} \%, 3.0 \mathrm{wt} \%$, and $5.0 \mathrm{wt} \%$, respectively; (f)

8123.0 wt \% Pd calcined at $773 \mathrm{~K}$ (Fig. S2A and Table S1); (g) $3.0 \mathrm{wt} \%$ Pd calcined at $813873 \mathrm{~K}$ (Fig. S2B and Table S1)). (B) Structures of catalysts corresponding to three 814 scales of particle sizes and proposed mechanism for $\mathrm{H}_{2} \mathrm{O}_{2}$ synthesis. Blue, red, white, 815 purple, and green spheres are palladium, oxygen, hydrogen, phosphorus, and calcium 816 atoms, respectively. 
Graphical abstract

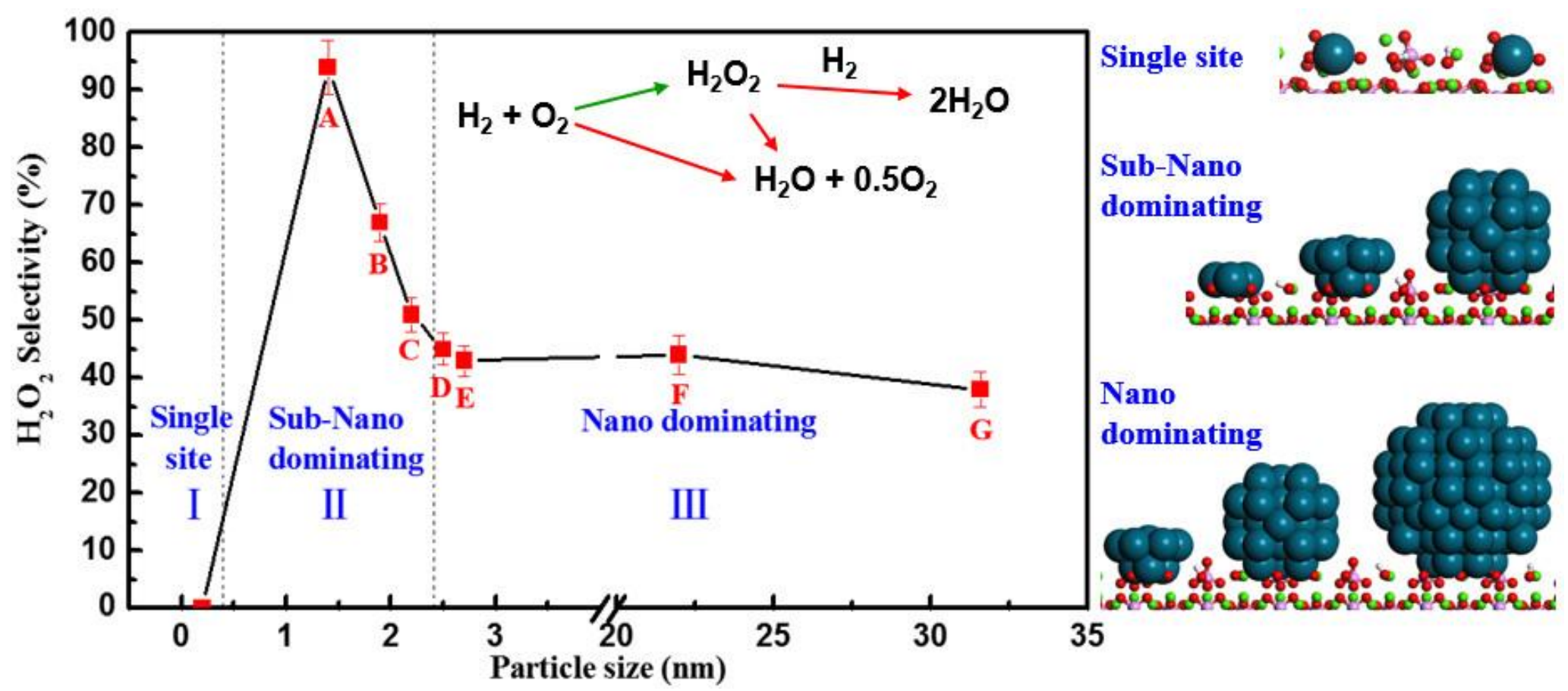

